\title{
Chapter 8 \\ Living on Cold Substrata: New Insights and Approaches in the Study of Microphytobenthos Ecophysiology and Ecology in Kongsfjorden
}

\author{
Ulf Karsten, Iris Schaub, Jana Woelfel, Duygu S. Sevilgen, Carolin Schlie, \\ Burkhard Becker, Angela Wulff, Martin Graeve, and Heiko Wagner
}

\begin{abstract}
Organisms in shallow waters at high latitudes are under pressure due to climate change. These areas are typically inhabited by microphytobenthos (MPB) communities, composed mainly of diatoms. Only sparse information is available on the ecophysiology and acclimation processes within MPBs from Arctic regions. The physico-chemical environment and the ecology and ecophysiology of benthic diatoms in Kongsfjorden (Svalbard, Norway) are addressed in this review. MPB biofilms cover extensive areas of sediment. They show high rates of primary production, stabilise sediment surfaces against erosion under hydrodynamic forces,
\end{abstract}

\section{U. Karsten $(\varangle) \cdot$ I. Schaub $\cdot$ C. Schlie}

Institute of Biological Sciences, Applied Ecology and Phycology, University of Rostock, Rostock, Germany

e-mail: ulf.karsten@uni-rostock.de

J. Woelfel

Department of Aquatic Ecology, Institute of Biological Sciences, University of Rostock, Rostock, Germany

D. S. Sevilgen

Alfred Wegener Institute, Helmholtz Centre for Polar and Marine Research, Bremerhaven, Germany

Max Planck Institute for Marine Microbiology, Bremen, Germany

B. Becker

Botanical Institute, University of Cologne, Cologne, Germany
A. Wulff
Department of Biological \& Environmental Sciences, University of Gothenburg,
Gothenburg, Sweden

M. Graeve

Alfred Wegener Institute, Helmholtz Centre for Polar and Marine Research,

Bremerhaven, Germany

H. Wagner

Institute of Botany, University of Leipzig, Leipzig, Germany 
and affect the exchange of oxygen and nutrients across the sediment-water interface. Additionally, this phototrophic community represents a key component in the functioning of the Kongsfjorden trophic web, particularly as a major food source for benthic suspension- or deposit-feeders.

MPB in Kongsfjorden is confronted with pronounced seasonal variations in solar radiation, low temperatures, and hyposaline (meltwater) conditions in summer, as well as long periods of ice and snow cover in winter. From the few data available, it seems that these organisms can easily cope with these environmental extremes. The underlying physiological mechanisms that allow growth and photosynthesis to continue under widely varying abiotic parameters, along with vertical migration and heterotrophy, and biochemical features such as a pronounced fatty-acid metabolism and silicate incorporation are discussed. Existing gaps in our knowledge of benthic diatoms in Kongsfjorden, such as the chemical ecology of biotic interactions, need to be filled. In addition, since many of the underlying molecular acclimation mechanisms are poorly understood, modern approaches based on transcriptomics, proteomics, and/or metabolomics, in conjunction with cell biological and biochemical techniques, are urgently needed.

Climate change models for the Arctic predict other multifactorial stressors, such as an increase in precipitation and permafrost thawing, with consequences for the shallow-water regions. Both precipitation and permafrost thawing are likely to increase nutrient-enriched, turbid freshwater runoff and may locally counteract the expected increase in coastal radiation availability. So far, complex interactions among factors, as well as the full genetic diversity and physiological plasticity of Arctic benthic diatoms, have only rarely been considered. The limited existing information is described and discussed in this review.

Keywords Microphytobenthos $\cdot$ Benthic diatoms $\cdot$ Polar regions $\cdot$ Climate change

\subsection{Introduction}

The Arctic Ocean is characterised by a large shelf area (depths of $<200 \mathrm{~m}$ ) that comprises approximately one-fifth of the global shelf (Menard and Smith 1966), resulting in extensive coastal regions with a mean water depth of less than $80 \mathrm{~m}$ (Gattuso et al. 2006; Jakobsson et al. 2008). The biomass of infaunal and epifaunal organisms in this extensive area is generally high compared to other, similar communities in temperate shallow-water regions, and thus responsible for high biological activity (Piepenburg et al. 1995; Sejr et al. 2000), in conjunction with high levels of benthic mineralisation (Rysgaard et al. 1998). All these organisms are strongly dependent on primary producers. Although pelagic and ice-related primary production in the Arctic can be high (Arrigo et al. 2008; Hodal et al. 2012), it typically has a narrow seasonal and local significance (Hsiao 1988). In addition, efficient microbial turnover rates for carbon and nutrients have been documented in 
the Arctic water column (Rysgaard et al. 1999), resulting in reduced sedimentation of particulate organic material. Consequently, at many locations in the Arctic, heterotrophic benthic organisms benefit little from the primary production of phytoplankton and ice-algae, and hence are dependent on benthic primary producers as their main food source (Glud et al. 2002). Benthic primary production in Arctic shallow-water regions is mainly mediated by seaweeds (Wiencke 2004; Fredriksen et al., Chap. 9), which form high standing-stock biomasses on hard substrata such as rocks; and by microphytobenthos (MPB) communities that grow mainly on soft sediments and as epiphytes on macroalgae (Karsten et al. 2006; Glud et al. 2009).

MPB communities are generally dominated by diatoms, which play an important role in the ecology of many Arctic coastal habitats (Glud et al. 2009). Glud et al. (2002) reported that at shallow depths, benthic microalgal productivity far exceeds that of pelagic microalgae, and can account for more than $90 \%$ of the total production. Similar studies on MPB productivity in subtidal Arctic regions remain scarce (Woelfel et al. 2010, 2014; Sevilgen et al. 2014), mainly due to the logistical constraints of high-latitude fieldwork. Nevertheless, the few data available from Arctic locations clearly indicate relatively high MPB primary production rates that are comparable to those from temperate regions (Glud et al. 2002, 2009; Woelfel et al. 2010, 2014; Sevilgen et al. 2014). In addition, MPB communities stabilise and modify sediment surfaces by the excretion of sticky extracellular polymeric substances (EPS) (De Brouwer et al. 2005), thereby reducing hydrodynamic erosion and acting as a biological filter (biofilm) for fluxes of oxygen and other elements at the sediment-water interface (Risgaard-Petersen et al. 1994). Consequently, MPB communities seem to be a key component in the functioning of trophic webs on soft substrates in Arctic coastal regions.

Many components of the pelagic and benthic food webs of higher trophic levels in the Arctic Kongsfjorden, a model ecosystem for high latitudes, are well described (Hop et al. 2002; Wiencke 2004). However, little information is available on the different primary producers, particularly benthic diatoms. The Arctic is currently facing a strong temperature increase due to global climate change (IPCC 2007; Bischof et al., Chap. 14). In addition to changes in hydrodynamics and local water temperatures, warming will entail enhanced freshwater input from melting snow, ice, glaciers and permafrost. This has consequences for coastal water salinity, sediment and nutrient runoff, as well as for the underwater light regime due to rising turbidity. In addition, drastic changes in the extent of sea-ice cover influences the light regime and consequently the potential time of onset of Arctic primary production throughout the year (Serreze et al. 2007; Zhang et al. 2012; Laxon et al. 2013), which might be beneficial for benthic primary producers. Furthermore, rising levels of $p \mathrm{CO}_{2}$ will lead to increased ocean acidification. Thus, the possible effects on MPB communities are indeed complex, and they must cope with altering conditions in the Arctic. The present review discusses ecological, physiological, bio(geo)chemical, cell-biological and molecularbiological aspects of benthic microalgae, in order to highlight their performance, interactions and acclimation potential under Arctic environmental conditions and global-change scenarios. Most of the data presented were obtained for benthic diatoms collected at different stations in Kongsfjorden and nearby Adventfjorden (Fig. 8.1). 


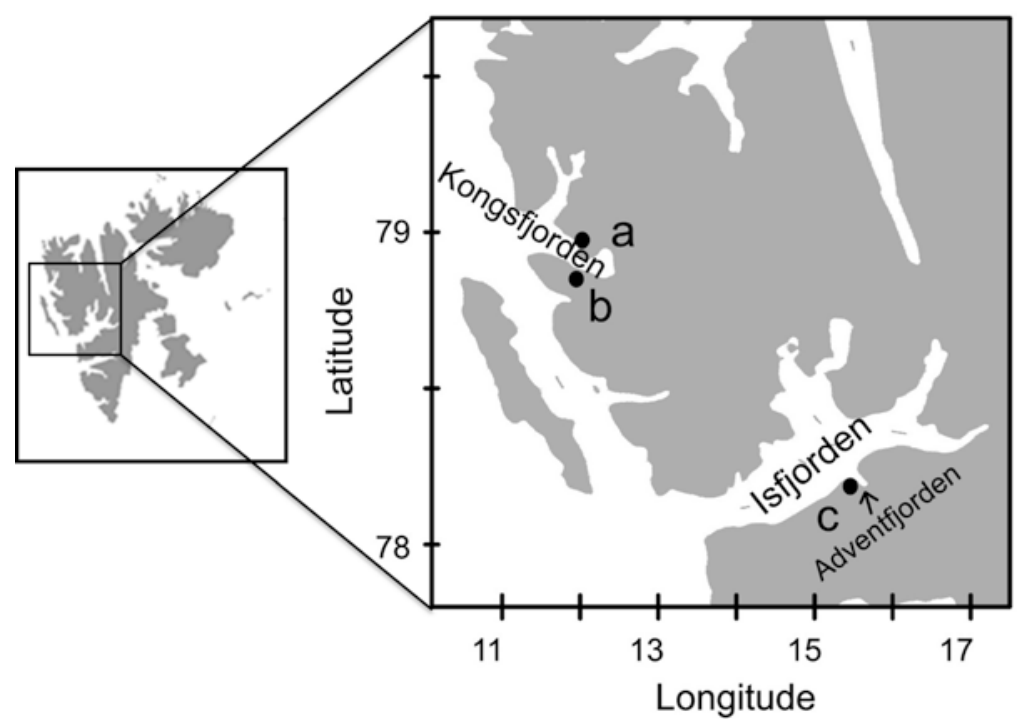

Fig. 8.1 Map of Svalbard showing Kongsfjorden and Adventfjorden, where all benthic diatoms were sampled. The black dots (a) and (b) indicate the London and Brandal stations in Kongsfjorden; dot (c) is the sampling location in Adventfjorden. For station details, see Woelfel et al. (2010)

\subsection{Physico-Chemical Environment of Kongsfjorden and MPB Acclimation and Adaptation}

Seasonally fluctuating solar radiation, low temperatures, and long periods of ice and snow cover are the key environmental factors controlling primary production in the Arctic (Hop et al. 2002).

\subsubsection{The Polar Night}

Benthic diatoms experience only short periods of sufficient light over the course of the year, with the polar day extending from mid-April until the end of August, and twilight conditions prevailing in spring and autumn (Svendsen et al. 2002). The polar night lasts for about 4 months, from the end of October to mid-February, and the annual surface incident solar radiation at $80^{\circ} \mathrm{N}$ is about $43 \%$ less than at the equator (Thomas et al. 2008). In the inner part of Kongsfjorden, the long period of winter darkness is further extended by the formation of sea ice, which breaks up sometime between April and July (Svendsen et al. 2002), although there has been much less ice in Kongsfjorden after 2006 (Cottier et al. 2007; Pavlova et al., Chap. 4). If the ice is also covered by snow, solar radiation can decrease to less than $2 \%$ of the surface level. Consequently, MPB communities may undergo as much as about 
10 months of darkness or very low light conditions (Chapman and Lindley 1980; Dunton 1990). In addition, MPB experience shifts to dark and partly anoxic conditions due to vertical migration into the sediment and because of burial by bioturbating animals (Petrowski et al. 2016).

\subsubsection{Dark Survival of Polar Benthic Diatoms}

Polar benthic diatoms from Kongsfjorden show a high potential for dark survival, as they can live up to 5 months in complete darkness (Schlie et al. 2011), which may be beneficial in the polar night. Other studies have shown that polar pelagic and benthic diatoms survive these long periods of darkness, although the maximum survival time seems to be species-specific (Bunt and Lee 1972; Palmisano and Sullivan 1983; Peters and Thomas 1996; Zhang et al. 1998). The underlying physiological, biochemical and molecular mechanisms are still poorly understood, such as, for example, the physiological state in which polar diatoms survive darkness.

Different potential adaptive mechanisms for long-term dark survival have been described (McMinn and Martin 2013). These mechanisms include the utilisation of stored energy products (Palmisano and Sullivan 1982), adjustment of metabolic rates (Peters and Thomas 1996), formation of resting stages (reviewed by McQuoid and Hobson 1996), or a facultative heterotrophic lifestyle (Hellebust and Lewin 1977; Armbrust et al. 2004). These adaptive mechanisms are not considered to be mutually exclusive, and probably vary in relative importance among polar species (Palmisano and Sullivan 1985).

\subsubsection{The Physiological State of Overwintering Diatoms in Kongsfjorden}

From an ecological perspective, growth is the most relevant indicator to describe the ecophysiological performance of algal species in a specific habitat, because it integrates all intracellular acclimation processes, both positive and negative (Schlie et al. 2011). Positive growth rates indicate that algae have intact cell structures and hence an intact metabolism. In order to assess biological changes in the cells during dark incubation, two fluorescent stains were applied to benthic diatoms from Kongsfjorden (C. Schlie unpubl.). The stains were SYTOX ${ }^{\circledR}$ Green Nucleic Acid Stain and PDMPO [2-(4-pyridyl)-5\{[4-dimethylaminoethyl-aminocarbamylmethoxy] phenyl oxazole]. SYTOX $^{\circledR}$ attaches to the DNA of the target organism (Veldhuis et al. 1997), which is only possible in non-vital cells with damaged cell membranes. The fluorophore PDMPO is co-deposited with silica into the newly synthesised cell wall of diatoms, so in addition to cell vitality, active growth can be observed and followed as bright-green fluorescence (Shimizu et al. 2001) (Fig. 8.2). 


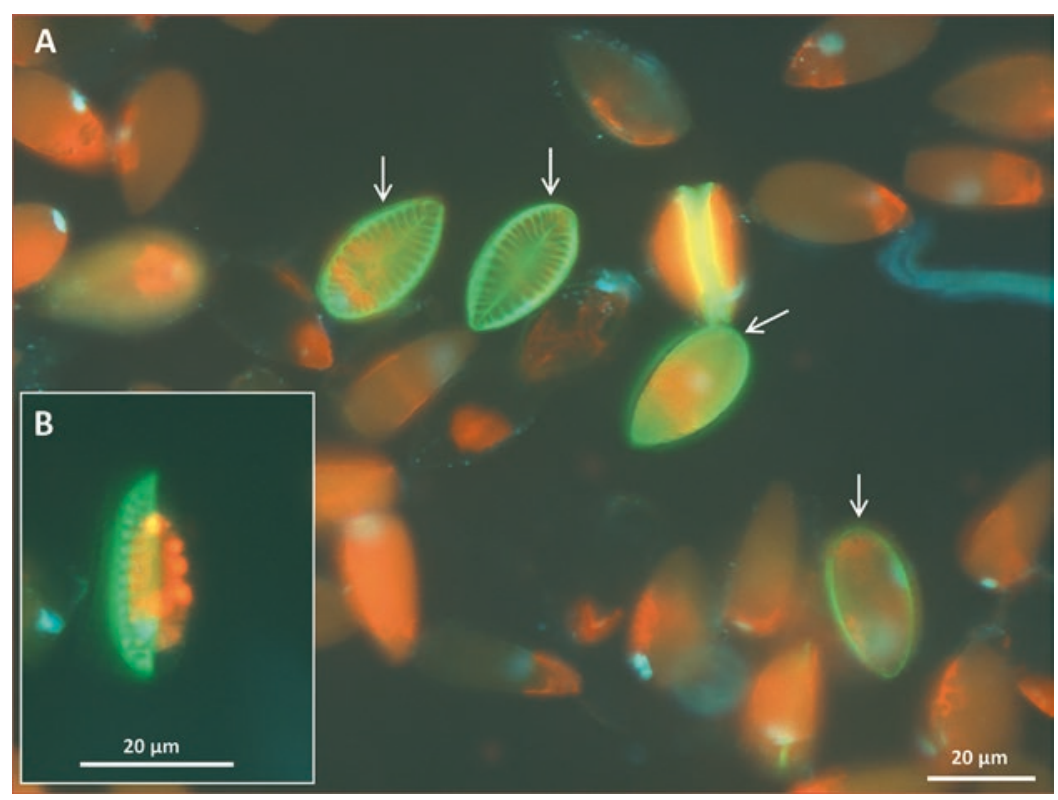

Fig. 8.2 Epifluorescence images of the benthic diatom Surirella cf. minuta from Kongsfjorden. (a) New silica deposition in the diatom valves as observed by using PDMPO [2-(4-pyridyl)-5 \{[4dimethylaminoethyl-aminocarbamyl-methoxy] phenyl\}oxazole] fluorescence probe (green colour), while the red colour originates from Chl. $a$ autofluorescence. Red colour is typical for older cells not involved in the latest cell growth, together with younger cells. The bright greencoloured structures (white arrows) indicate newly synthesised valves (silica incorporation), viewed from above. (b) Newly synthesised valves seen from lateral position. (C. Schlie et al. unpubl.)

Applying SYTOX and PDMPO to the benthic diatom Surirella cf. minuta during 5 months of darkness indicated that an increasing number of cells exhibited damage over time, although after 1 month about $80 \%$ were still viable (C. Schlie et al. unpubl.). In addition, active silica incorporation in the dark was measured, i.e. $5 \%$ of all diatom cells showed staining after 2 months of darkness, indicating that growth processes were continuing (Schlie et al. unpubl.) (Fig. 8.2).

Experiments on the dark-survival potential were performed with a Kongsfjorden isolate of the benthic diatom Cylindrotheca closterium (Schlie et al. 2011). This species was kept for more than 5 months in darkness, and sub-samples were re-irradiated each month with continuous low irradiances $\left(2.2-3.3 \mathrm{~W} \mathrm{~m}^{-2}\right)$. After 1, 2, 3 and 5 months of dark incubation, $C$. closterium showed high growth rates in the light within a few days, indicating a high capability of withstanding the polar night (Schlie et al. 2011). However, chloroplast size was reduced with increasing incubation time.

Originally ovoid chloroplasts of $S$. cf. minuta from Kongsfjorden shrunk after 2 weeks in darkness (C. Schlie unpubl.). Photosynthetic pigments begin to degrade after a few days without light. In particular, chlorophyll degradation provides nitrogen for maintenance metabolism. Karsten et al. (2012) mentioned that the benthic Fragilaria striatula from Kongsfjorden showed a 30-40\% reduction in chloroplast 
length after 3 months of darkness, indicating a reallocation of energy towards maintenance metabolism through the decomposition of organelle components. After reirradiation, this diatom had a long lag-phase before growth resumed. Other benthic diatoms from Kongsfjorden showed increasingly long lag-phases as a function of a longer dark incubation period, before optimum growth could be re-established (Karsten et al. 2012). This lag-phase includes a recovery period, in which the diatoms acclimate to sudden light conditions after dark treatment, rebuilding their cell structures and metabolism. The length of the lag-phase seems to be species-specific in benthic diatoms from Kongsfjorden (Karsten et al. 2012).

\subsubsection{The Biochemical State of Overwintering Diatoms in Kongsfjorden}

From a biochemical viewpoint, the utilisation of storage products, such as carbohydrates and lipids, can provide energy for the cellular maintenance metabolism during long-term darkness. The principal storage products in diatoms consist of the carbohydrate chrysolaminarin and the neutral lipid triacylglycerol, which are stored in cell vacuoles and in cytoplasmic lipid droplets, respectively (Beattie et al. 1961; Darley 1977).

High proportions of lipid droplets have previously been detected in species of polar phytoplankton and ice diatoms in late autumn (Fryxell 1989; Zhang et al. 1998). In the benthic diatom Nitzschia cf. dubiiformis, from Adventfjorden, Svalbard, large amounts of cytoplasmic lipid droplets were observed (Schaub et al. 2017; Fig. 8.3). During 12 weeks of dark incubation, this species exhibited a continuous decrease in the volume of the lipid droplets, indicating intracellular

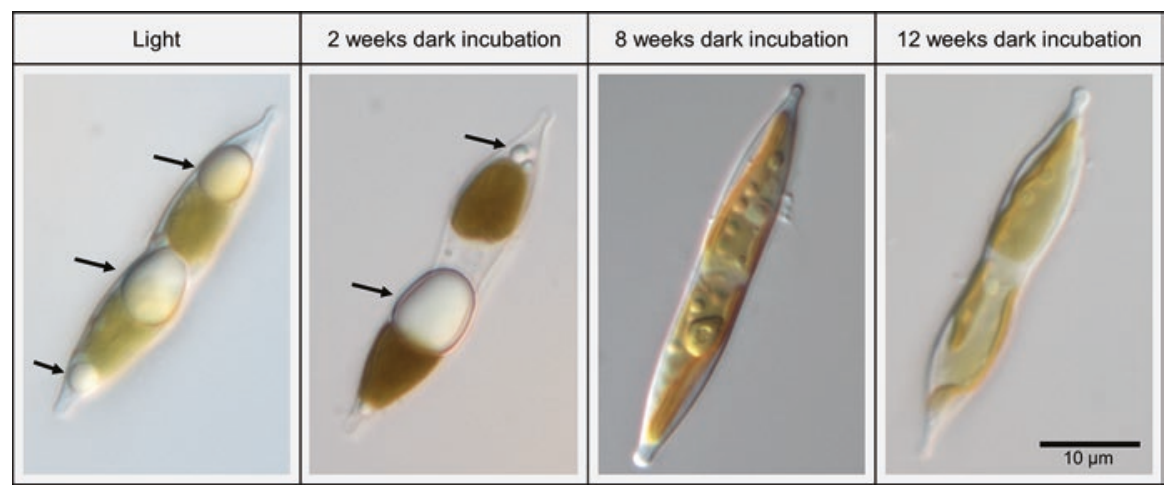

Fig. 8.3 Cells of the benthic diatom Nitzschia cf. dubiiformis from Adventfjorden, Svalbard, grown under light conditions (late log phase) and after 2, 8 and 12 weeks of darkness. Black arrows indicate lipid droplets in the cell. Cells were kept in a batch culture under $25 \mu \mathrm{mol}$ photon $\mathrm{m}^{-2} \mathrm{~s}^{-1}$ in a 16:8 h light:dark rhythm, at $8{ }^{\circ} \mathrm{C}$ in $\mathrm{F} / 2$ medium with metasilicate $\left(0.6 \mathrm{ml} \mathrm{l}^{-1}\right)$ and a salinity of 33. Photomicrographs were made with an Olympus BX51 microscope and ColorView 12 
degradation and, most probably, utilisation for maintenance metabolism (Schaub et al. 2017). Smith and Morris (1980) observed that diatoms from the Southern Ocean showed enhanced incorporation of $80 \%$ of the assimilated carbon into the lipid fraction under conditions of low irradiance $\left(12.5 \mathrm{~W} \mathrm{~m}^{-2} \mathrm{PAR}\right.$ - photosynthetically active radiation, 400-700 nm) and low temperature $\left(-1.0{ }^{\circ} \mathrm{C}\right)$, compared to carbohydrate synthesis under higher temperature $\left(+0.2^{\circ} \mathrm{C}\right)$ and irradiance (305.4 $\mathrm{W} \mathrm{m}^{-2}$ PAR).

The two major lipid classes in diatoms are (i) polar lipids (glycolipids, sulfolipids and phospholipids), and (ii) neutral lipids such as triacylglycerols (TAG) and free fatty acids (Dunstan et al. 1993). Polar lipids are common membrane components, consisting of high proportions of polyunsaturated fatty acids (PUFA). TAG generally have more saturated (SFA) and monounsaturated fatty acids (MUFA) (Sukenik and Wahnon 1991), and serve primarily as a form of carbon and energy storage (Dunstan et al. 1993). Since lipids are important for energy storage in polar benthic diatoms, qualitative and quantitative analytical methods are crucial to understand the catabolic pathways that contribute to darksurvival mechanisms. Examining different lipid classes or fatty-acid composition of diatoms requires the use of high-performance liquid chromatography (HPLC) or gas-liquid chromatography (GC), often in combination with mass spectrometry (MS) (Christie 1996; Kattner and Fricke 1986; Nordbäck et al. 1998; Graeve and Janssen 2009). Total lipid content can be determined in intact diatom cells using Fourier transform infrared (FTIR) spectroscopy (Wagner et al. 2014; Schaub et al. 2017).

In order to understand the utilization of lipophilic storage products during the polar night, Nitzschia cf. dubiiformis from Adventfjorden was exposed to up to 8 weeks of darkness, with weekly analyses of fatty acid and total lipid content using GC-MS (Fig. 8.4) and FTIR in parallel (Fig. 8.5). Total fatty acid content per cell decreased sharply (by about 50\%) in the first 2 weeks, with much slower degradation rate thereafter (Fig. 8.4). The ratio of SFA + MUFA/PUFA decreased continuously from 1.70 after the first week of darkness to 1.47 after 8 weeks without light, indicating greater reduction of MUFA and SFA than of PUFA. Since TAG consists mainly of MUFA and SFA, it can be assumed that Arctic benthic diatoms preferentially use this storage product during long-term darkness. In contrast, FTIR measurements showed a decrease in the overall lipid content (Fig. 8.5a, b; lipid ester, wavenumber $1700-1800 \mathrm{~cm}^{-1}$ ) after the first week, and a sharp second decrease after the fourth week of dark incubation, which was also reflected in a strong increase in the amide/lipid ratio (Fig. 8.5c). This confirms that lipids are the principal storage products during prolonged darkness. Furthermore, the chrysolaminarin peak (Fig. 8.5a, wavenumber $1300-1400 \mathrm{~cm}^{-1}$ ) decreases strongly during the first week of darkness, indicating a rather short-term degradation of this carbohydrate storage compound (Schaub et al. 2017). 


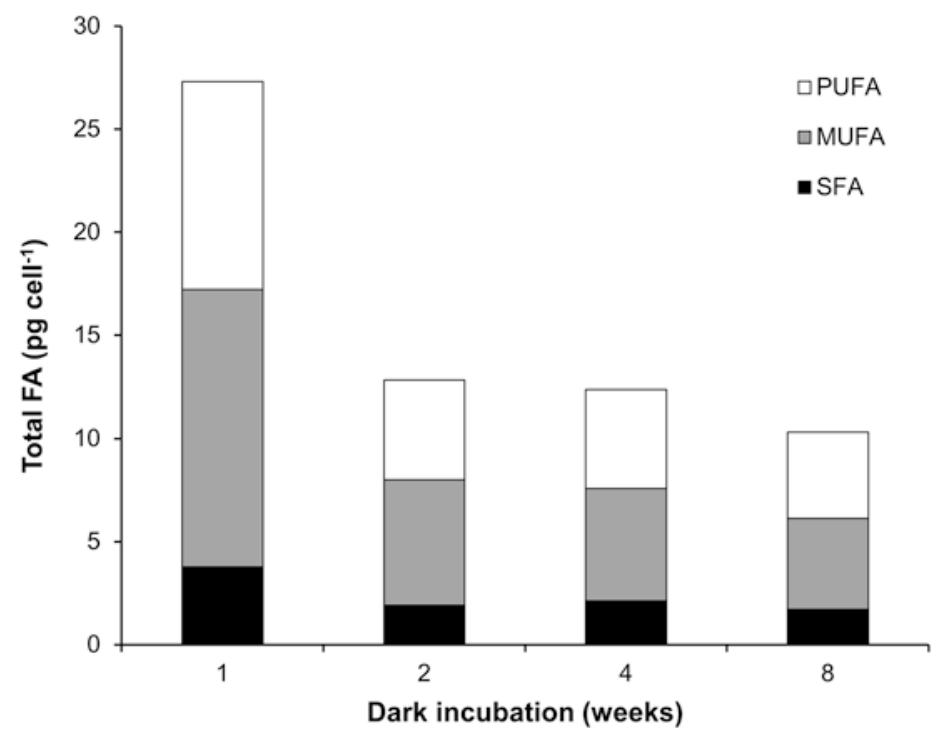

Fig. 8.4 Total fatty-acid content (pg cell ${ }^{-1}$ ) in the benthic Nitzschia cf. dubiiformis from Adventfjorden, Svalbard, under 1, 2, 4, and 8 weeks of dark incubation at a temperature of $8{ }^{\circ} \mathrm{C}$. Total fatty-acid content, determined with GC/MS, is separated into polyunsaturated (PUFA), monounsaturated (MUFA) and saturated (SFA) fatty acids. Incubation in F/2 medium with metasilicate $\left(0.6 \mathrm{ml} \mathrm{l}^{-1}\right)$ at a salinity of 33

\subsubsection{The Underwater Light Climate in Kongsfjorden}

With the onset of the polar day in spring, the ice cover in Kongsfjorden produces dim light conditions, even in shallow waters. After the sea ice break-up in spring, solar radiation penetrates deeply into the water column, except in the inner bay. UV-radiation (UVR) and blue light are strongly attenuated in coastal waters because of the prevailing optical properties, which are influenced by particles (from e.g. glaciers) and yellow substances originating from meltwater and terrestrial runoff (Hanelt et al. 2001; Pavlov et al., Chap. 5). In the Arctic summer, even at noon the angle of the sun is always low, resulting in maximum surface irradiances of $283 \mathrm{~W} \mathrm{~m}^{-2}$ PAR (400-700 nm), $19 \mathrm{~W} \mathrm{~m}^{-2}$ UV-A (320-400 nm) and $1.1 \mathrm{~W} \mathrm{~m}^{-2}$ UV-B (280-320 nm) (Bischof et al. 1998). The 1\% depth for UV-B radiation, which represents the approximate threshold irradiance of UVB with potential to negatively affect primary plant productivity, is between 4 and $8 \mathrm{~m}$ in Kongsfjorden (Hanelt et al. 2001). Peak irradiances during clear-water periods may reach a maximum of $40 \mathrm{~W} \mathrm{~m}^{-2}$ PAR at $5 \mathrm{~m}$ water depth, however for a few weeks only, followed by much lower values between 5 and $10 \mathrm{~W} \mathrm{~m}^{-2}$ PAR due to increasing turbidity (Bischof et al. 2002). During late spring and early summer, water transparency in Kongsfjorden decreases sharply, due to the development of phytoplankton blooms and the inflow of meltwater (Pavlov et al., Chap. 5). With increasing turbidity, the irradiance decreases and spectrum shifts from blue to green wavebands in deeper waters 


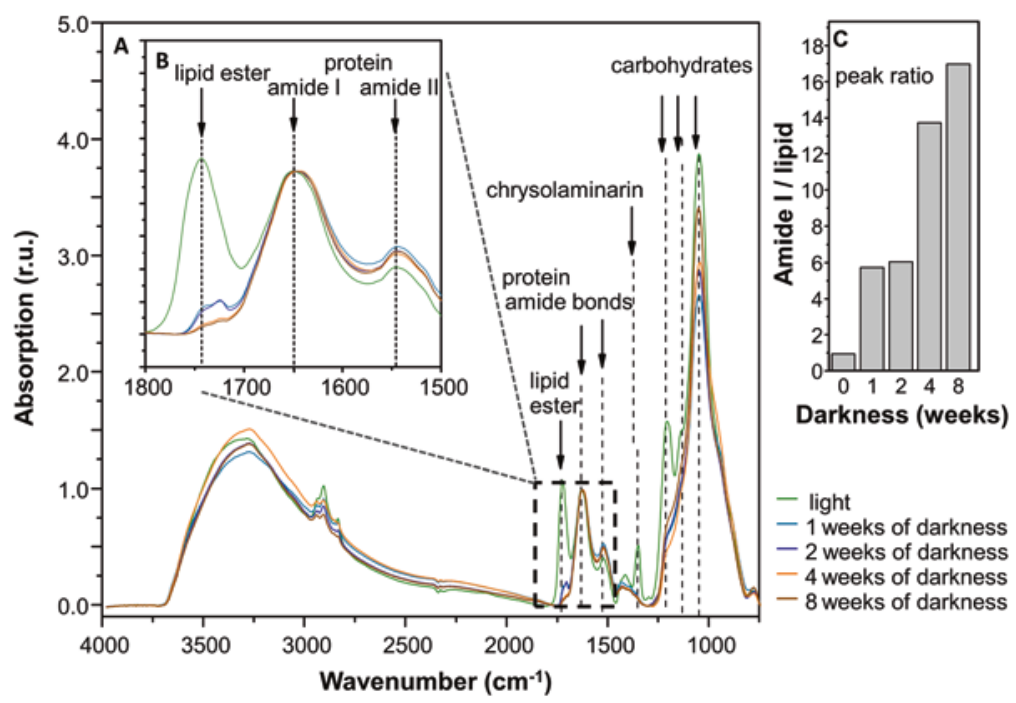

Fig. 8.5 Fourier transform infrared (FTIR) spectra of Nitzschia $\mathrm{cf}$. dubiiformis from Adventfjorden, to determine changes in the cellular macromolecular composition according to Wagner et al. (2010). Cell spectra were measured after prolonged darkness of 8 weeks at $0{ }^{\circ} \mathrm{C}$ to follow the changes in lipid content (a). Inset (b) shows a magnification of the waveband range between 1500 and $1800 \mathrm{~cm}^{-1}$. Peak ratios (c) for the protein:lipid content have been quantified from the amide I absorption band (showing the amide bond of proteins at $1649 \mathrm{~cm}^{-1}$ ) and the lipid ester bond $\left(1740 \mathrm{~cm}^{-1}\right)(\mathbf{b})$. Spectra were plotted as relative units (r.u.)

(Jerlov 1976). Consequently, benthic diatoms in Kongsfjorden experience widely fluctuating radiation conditions both seasonally and diurnally, and most of the time they live under a low light environment of $<5-10 \mathrm{~W} \mathrm{~m}^{-2} \mathrm{PAR}$, without biologically harmful UVR (Woelfel et al. 2014).

\subsubsection{The Acclimation of Polar Benthic Diatoms to Low Light}

The few data available on benthic diatoms from Kongsfjorden indicate a very high capability to acclimate to the prevailing irradiances and continue photosynthesis (Karsten et al. 2006, 2012; Woelfel et al. 2010, 2014; Sevilgen et al. 2014).This high adaptive capacity is well supported by similar studies from Greenland (Kühl et al. 2001) and Antarctica (Wulff et al. 2008, 2009). Even under extremely low irradiances of $0.1,1.1$ and $2.2 \mathrm{~W} \mathrm{~m}^{-2}$ PAR, high growth rates were reported for Nitzschia cf. aurariae (Karsten et al. 2012) and two Fragilaria species (Karsten et al. 2006). Support for the shade acclimation of benthic diatoms in polar areas derives also from their low light requirements for photosynthesis. The Antarctic benthic diatom Trachyneis aspera was able to grow at ambient radiation of $<0.6 \mu \mathrm{mol}$ photons $\mathrm{m}^{-2} \mathrm{~s}^{-1}\left(=0.13 \mathrm{~W} \mathrm{~m}^{-2} \mathrm{PAR}\right)$, with saturated photosynthetic rates ( $\mathrm{E}_{\mathrm{k}}$ values) between 7 and $16 \mu \mathrm{mol}$ photons $\mathrm{m}^{-2} \mathrm{~s}^{-1}\left(=1.5\right.$ and $3.5 \mathrm{~W} \mathrm{~m}^{-2} \mathrm{PAR}$ ) (Palmisano et al. 1985). 
Adaptation to low light is also apparent in the reported low half-saturation and compensation irradiances for the entire MPB community from Brandal, Kongsfjorden (Sevilgen et al. 2014). By virtue of their low light requirements for photosynthesis, benthic diatoms are capable of successfully colonising deep bottoms. McGee et al. (2008) found living benthic diatoms even at a water depth of $191 \mathrm{~m}$, where the midday insolation averaged $0.1 \mu \mathrm{mol}$ photons $\mathrm{m}^{-2} \mathrm{~s}^{-1}$ (= $0.02 \mathrm{~W} \mathrm{~m}^{-2} \mathrm{PAR}$ ), i.e. $<0.03 \%$ of surface incident radiation. The ability of benthic diatoms to acclimate not only to such extreme low-light conditions but also to highlight conditions in Antarctica (up to $350 \mathrm{~W} \mathrm{~m}^{-2} \mathrm{PAR}$ ) has been reported, emphasising that polar benthic diatoms are very well adapted to fluctuating radiation conditions (Wulff et al. 2008; Salleh and McMinn 2011).

\subsubsection{Vertical Migration as a Response to Fluctuating Light Conditions}

Vertical migration of benthic diatoms has been recognised as a main factor controlling the short-term variability of MPB productivity. The migratory patterns in subtidal benthic diatoms are closely linked to the diel cycle, and vertical migration is more affected by the photoperiod than by a combination of light and physical/ hydrodynamic regimes (Longphuirt et al. 2006; Du et al. 2010).

Published studies on vertical migration of benthic diatoms in high-latitude regions with polar day and night conditions are lacking. Sevilgen et al. (unpubl.) recorded ex situ surface chlorophyll $a$ concentrations in MPB communities in intact sediment cores from Kongsfjorden using back-reflectance spectra of the surface as a proxy for migration patterns. Two scenarios reflecting the Arctic summer and a temperate day/night light cycle were applied (Fig. 8.6). Chl. $a$ showed a decline in concentration with decreasing photon fluence rates, and vice versa, indicating vertical migration of MPB (Fig. 8.6). In addition, the appearance and disappearance of the typical brownish benthic diatom layer (fucoxanthin) on the sediment surface could be followed visually.

In a similar study, the heterogeneity of benthic diatom occurrence, caused by vertical migration as well as patchiness, was studied by IMAGING-PAM (Pulse Amplitude Modulation) analysis (IMAG-MIN, Walz, Efferich, Germany) in sediment cores from Kongsfjorden (Fig. 8.7) (J. Woelfel unpubl.; stations according to Woelfel et al. [2014]).

The top $5 \mathrm{~mm}$ sections of sediment cores were measured at $2{ }^{\circ} \mathrm{C}$, following a specific protocol: (1) 2-D images of the fluorescence parameters $\mathrm{F}_{0}$ (minimum fluorescence of dark-acclimated cells) and $F_{m}$ (maximum fluorescence under saturating light) were taken after 10 min dark adaptation. (2) The cores were then exposed to three increasing photon fluence rates, each provided for $15 \mathrm{~min}$ : low light (LL, $15 \mu \mathrm{mol}$ photons $\mathrm{m}^{-2} \mathrm{~s}^{-1}$ ), medium light (ML, $100 \mu \mathrm{mol}$ photons $\mathrm{m}^{-2} \mathrm{~s}^{-1}$ ) and high light (HL, $1000 \mu \mathrm{mol}$ photons $\mathrm{m}^{-2} \mathrm{~s}^{-1}$ ). After 5, 10 and $15 \mathrm{~min}, \mathrm{~F}_{0}$ and $\mathrm{F}_{\mathrm{t}}$ (fluorescence in the light) were determined with low measuring light, followed by 


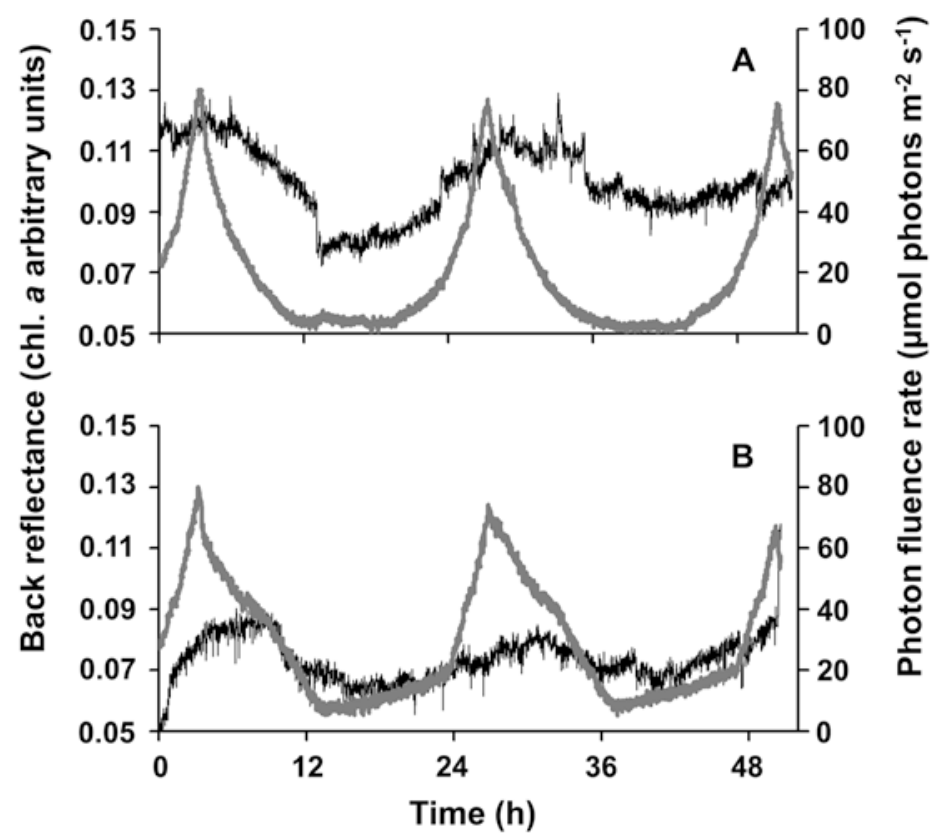

Fig. 8.6 Relative surface chlorophyll $a(\mathrm{Chl} . a)$ changes as derived from back-reflectance measurements in sandy sediment cores from Brandal station (5 m), Kongsfjorden, in July 2012. (a) Relative Chl. $a$ changes with mimicked in situ light dynamics (polar summer); and (b) changes with mimicked light conditions of a temperate region (6 h of darkness). Vertical lines in photon fluence rates reflect temporal shading of the setup due to experimental reasons. Grey line: photon fluence rate; black line: relative Chl. $a$ units. (D.S. Sevilgen et al. unpubl.)

maximal fluorescence $\mathrm{F}_{\mathrm{m}}$ and $\mathrm{F}_{\mathrm{m}^{\prime}}$ (maximum fluorescence under actinic light) after applying a $800 \mathrm{~ms}$ saturating light pulse. (3) Exposure to $30 \mathrm{~min}$ darkness followed by measurements of all parameters during dark recovery.

All fluorescence parameters decreased with increasing photon fluence rates, followed by a subsequent increase during the 30-min dark period (Fig. 8.7). These changes in $\mathrm{F}_{0} / \mathrm{F}_{\mathrm{t}}$ and $\mathrm{F}_{\mathrm{m}} / \mathrm{F}_{\mathrm{m}^{\prime}}$ could, in principle, reflect either vertical migration of benthic diatoms or a down-regulation of Chl. $a$ fluorescence excitation. The strong decrease of both $\mathrm{F}_{0} / \mathrm{F}_{\mathrm{t}}$ and $\mathrm{F}_{\mathrm{m}} / \mathrm{F}_{\mathrm{m}^{\prime}}$ is interpreted as a migratory response to increasing light levels due to the short time intervals used in the experiments. Nonphotochemical quenching (NPQ) is a photoprotective mechanism against excessive irradiance. NPQ increased continuously under more-intense light, and decreased during the dark treatment. This pattern led, partly, to decreases in $\mathrm{F}_{\mathrm{m}^{\prime}}$. The incomplete recovery within $30 \mathrm{~min}$ in darkness can be explained by the possible "resting" of motile diatoms in the sediment, since these algae need a radiation impulse for upward migration (L. Polerecky, MPI for Marine Microbiology, Bremen, pers. comm.). 
Fig. 8.7 Changes in the fluorescence parameter $\mathrm{F}_{0}$ (a), after irradiation parameter $\mathrm{F}_{\mathrm{m}^{\prime}}(\mathbf{b})$ and non-photochemical quenching (NPQ) (c) in surface sediment cores. Data, shown as mean $\pm \mathrm{SD}$, were plotted over time ( $\mathrm{min}$ ) and as a function of irradiance: Low light $(\mathrm{LL})=15$, medium light $(\mathrm{ML})=100$ and high light $(\mathrm{HL})=1000 \mu \mathrm{mol}$ photons $\mathrm{m}^{-2} \mathrm{~s}^{-1}$. Data represent samples from three stations in Kongsfjorden (BRL, NAT, LON). Grey bars indicate periods of dark adaptation as well as increasing levels of irradiance. (J. Woelfel et al. unpubl)
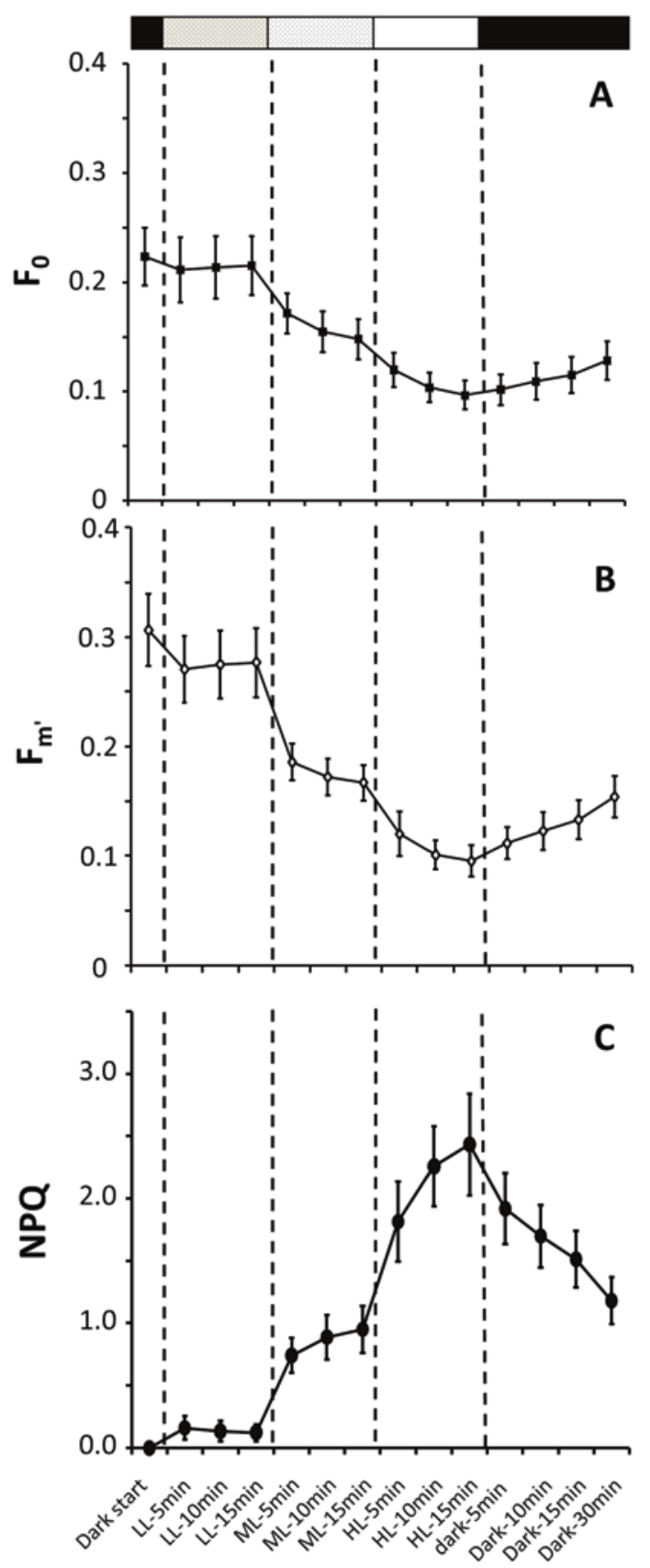

Treatments 


\subsubsection{The Prevailing Water Temperature in Kongsfjorden}

While solar radiation exhibits extreme seasonal qualitative and quantitative variability, temperatures in Kongsfjorden change only slightly, between $-1.8^{\circ} \mathrm{C}$ in winter and about $5.0^{\circ} \mathrm{C}$ in summer (Hanelt et al. 2001), although local temperature fluctuations can reach $8.8{ }^{\circ} \mathrm{C}$ (D.S. Sevilgen unpubl.). However, there are strong indications that this rather typical temperature regime changed after a massive intrusion of warmer Atlantic-derived water masses into the fjord in February 2006 (Cottier et al. 2007). The resulting warmer period of Kongsfjorden over the last 7-8 years overlapped with a period of very small amounts of drift ice on the shelf west of Svalbard (Kwasniewski et al. 2012). Arctic water masses have generally warmed by $0.7-1.2{ }^{\circ} \mathrm{C}$ per decade since 1981 (Serreze and Francis 2006), with unknown consequences for the MPB and other marine organisms (Hegseth and Tverberg 2013). Independently of the underlying mechanisms, the signs of continuing warming of the Arctic Ocean are numerous (Polyakov et al. 2005; Overland et al. 2014). The annual mean temperature from June 2011 until June 2012 was $2.4+/-2.1^{\circ} \mathrm{C}$ at the shallow (5 m water depth) coastal sandy sediment site of Brandal in Kongsfjorden (Sevilgen et al. 2014). However, during summer, water temperatures can temporarily increase to over $8^{\circ} \mathrm{C}$ at this station, and exhibit a wide dynamic range, with daily temperature fluctuations of up to $5{ }^{\circ} \mathrm{C}$ (Sevilgen et al. unpubl.). In contrast, the temperatures in deeper waters $>5 \mathrm{~m}$ were relatively constant, ranging from 1 to $5{ }^{\circ} \mathrm{C}$ from June through August in 2006, 2007, 2008 and 2011 (Woelfel et al. 2009, 2010, 2014; D.S. Sevilgen unpubl.).

\subsubsection{The Influence of Water Temperature on Growth}

Temperature has a major influence on MPB growth rates (Karsten et al. 2006; Schlie et al. 2011). Arctic benthic diatoms seem to require higher temperatures than do endemic Antarctic species. Two Fragilaria species from Kongsfjorden showed optimum growth rates at $12-14{ }^{\circ} \mathrm{C}$, grew more slowly at $0{ }^{\circ} \mathrm{C}$, and did not survive at $20{ }^{\circ} \mathrm{C}$ (Karsten et al. 2006). Similarly, Nitzschia cf. aurariae from the same location grew at temperatures between 5 and $15{ }^{\circ} \mathrm{C}$, did not grow at $0{ }^{\circ} \mathrm{C}$, and died at $23{ }^{\circ} \mathrm{C}$ (Karsten et al. 2012). The optimum growth temperature for $N$. cf. aurariae was $15^{\circ} \mathrm{C}$, which clearly indicates moderate temperature requirements. Schlie and Karsten (2017) studied eight benthic diatom species isolated from Adventfjorden (Svalbard, Norway), and confirmed as a general response patterns a preference for 6-15 ${ }^{\circ} \mathrm{C}$. Thus, Arctic benthic diatoms can be characterised as eurythermal and psychrotolerant microalgae (organisms tolerant of low growth temperatures), and hence they will be able to cope well with the predicted increasing water temperatures. This is in sharp contrast to a related endemic Antarctic benthic diatom, Odontella litigiosa, which typically exhibits maximum growth at $0{ }^{\circ} \mathrm{C}$ and complete inhibition of cell division at $7-9{ }^{\circ} \mathrm{C}$ (Longhi et al. 2003). It is reasonable to assume that other 
Antarctic benthic diatoms might also be rather polar stenothermal and psychrophilic (i.e., require low temperatures for growth), as has been reported for many Antarctic seaweeds (Wiencke and tom Dieck 1990).

\subsubsection{Salinity Fluctuations in Kongsfjorden and Their Effects on Benthic Diatoms}

While salinity is a relatively constant factor in the offshore region of all oceans, it may vary both locally and seasonally in the near-shore water of Kongsfjorden due to the high volume of meltwater runoff, particularly during summer (Hanelt et al. 2001). Horizontal and vertical gradients between freshwater and fully marine conditions are apparent in the fjord (Svendsen et al. 2002). In addition, hydrological conditions, wind, precipitation and evaporation can influence salinity. During periods of calm weather, water bodies often develop a freshwater layer above the denser seawater. However, due to wave- and wind-induced vertical mixing, deeper water layers in Kongsfjorden can also be affected by freshwater runoff, with reductions in salinity from 33 to 20, down to about 20-m depth (Hanelt et al. 2001).

The effect of salinity on benthic diatoms in Arctic waters is generally little studied. Nitzschia cf. aurariae from the Kongsfjorden MPB grows in salinities between 15 and 45 (Karsten et al. 2012). The highest growth rates occur between salinities of 20 and 40, and growth is inhibited at 10 and 50 (Karsten et al. 2012). Therefore, Nitzschia cf. aurariae exhibits a growth-response pattern that can be characterised as moderately euryhaline. The underlying mechanisms, such as osmotic acclimation, have not yet been studied in Arctic benthic diatoms.

\subsubsection{Nutrient Availability in Kongsfjorden for Benthic Diatoms}

The European Arctic is one of the most productive marine regions in the world (Arrigo and van Dijken 2011), since nutrient-rich water enters from the south during part of the year via the West Spitsbergen Current. While nitrogen and phosphorus concentrations in the water column are relatively high during the winter months, both macronutrients are almost fully depleted in summer after the phytoplankton blooms. In contrast, benthic diatoms benefit from the high nutrient levels in the sediment pore water, where dissolved inorganic nitrogen (DIN) levels, ranging from 1.9 to $36.7 \mathrm{mM}$ and soluble reactive phosphorous (SRP) from 0.9 to $5 \mathrm{mM}$, are generally much higher (approximately 5-20-fold) than in the overlying water column (Woelfel et al. 2009), and probably available year-round. This suggests that benthic diatoms in Kongsfjorden are not nutrient-limited. 
Table 8.1 Annual primary production $\left(\mathrm{g} \mathrm{C} \mathrm{m}^{-2}\right.$ year $\left.^{-1}\right)$ estimates in Kongsfjorden, Svalbard

\begin{tabular}{l|l|l|l}
\hline & Study period & $\mathrm{g} \mathrm{C} \mathrm{m}^{-2}$ year $^{-1}$ & Reference \\
\hline \multirow{3}{*}{ Pelagic } & July 1996 & $4-180$ & Hop et al. (2002) \\
\cline { 2 - 4 } & July $1979 / 1980$ & 150 & Eilertsen et al. (1989) \\
\cline { 2 - 4 } & April/May 2002 & $27-35$ & Hodal et al. (2012) \\
\hline \multirow{3}{*}{ Benthic } & July 2008 & 71 & Woelfel et al. (2010) (Kongsfjorden) $^{\mathrm{b}}$ \\
\cline { 2 - 4 } & July 2008 & 165 & Woelfel et al. (2010) (Brandal) $^{\mathrm{b}}$ \\
\cline { 2 - 4 } & June-July 2010 & 49.2 & Sevilgen et al. (2014) \\
\hline
\end{tabular}

${ }^{\text {a}}$ Spring only (18 April-13 May); ${ }^{\text {E} E s t i m a t e s ~ c a l c u l a t e d ~ f o r ~} 90$ light days

\subsubsection{Hydrodynamic Conditions}

In polar coastal areas with high wave energy, benthic communities are often strongly impacted by icebergs and rafted sea ice, which can reach depths of about $40 \mathrm{~m}$ and thereby scrape the sea floor, resulting in disturbance or even mechanical damage (Gutt 2001). In Kongsfjorden, area Chl. $a$ values as a proxy for MPB biomass varied from 49 to $165 \mathrm{mg} \mathrm{m}^{-2}$ (Table 8.1), and were related to water depth, current or wave exposure, as well as geographical location (Woelfel et al. $2009,2010)$. In contrast, MPB biomass was independent of other abiotic parameters such as sediment properties, salinity or temperature (Woelfel et al. 2009), and Chl. $a$ levels did not correlate with primary production rates (Woelfel et al. 2010). However, hydrodynamic conditions seem to be a driving force for differences in sediment colonisation by benthic diatoms. One study from a temperate region indicates that increasing the current velocity from $15 \mathrm{~cm} \mathrm{~s}^{-1}$ to $40 \mathrm{~cm} \mathrm{~s}^{-1}$ stimulates photosynthesis and other physiological and biochemical processes in benthic diatoms (Lamb and Lowe 1987).

\subsection{Biodiversity of Benthic Diatoms in Kongsfjorden}

Biodiversity is important for the function of benthic diatoms. Recent investigations of benthic diatoms from Kongsfjorden and Adventfjorden have provided the first floristic list for these ecosystems (Stachura-Suchoples et al. 2016; Fredriksen et al., Chap. 9). The list of 47 identified diatom species forms a baseline for a high-latitude fjord system (Fredriksen et al., Chap. 9). The data from these studies reveal a highly variable community with a patchy, heterogeneous distribution of most taxa. The MPB communities likely change over time because of prevailing dynamic, seasonally changing environmental parameters, which act as strong structuring forces (Fredriksen et al., Chap. 9). 


\subsection{Primary Production of Benthic Diatoms in Kongsfjorden}

In contrast to temperate coastal ecosystems, only a few studies have examined MPB primary production in Arctic regions. The latest review of benthic microalgal production in Arctic waters (Glud et al. 2009) comprised 10 peer-reviewed and three unpublished studies of shelf areas off Siberia, Svalbard, Greenland and North America. As indicated in this review, the productivity of benthic polar microalgae exceeds the pelagic productivity by a factor of 1.5 for water depths down to $30 \mathrm{~m}$, and hence benthic diatom assemblages may represent an important organic food source for zoobenthos. Since the review of Glud et al. (2009), few additional studies have addressed Arctic MPB primary production (Woelfel et al. 2010, 2014; Attard et al. 2014; Sevilgen et al. 2014). All these studies pointed out that Arctic MPB communities contribute significantly to coastal ecosystem production, and therefore need to be taken into account for carbon budget calculations.

Although Kongsfjorden is considered a model high-latitude ecosystem with abundant available data, basic information on benthic primary production of the different phototrophic organisms was lacking for a long time (Hop et al. 2002). To fill this gap, primary production of MPB was determined during various summer expeditions between 2006 and 2012 at several soft-sediment stations along the coastline of Kongsfjorden (Woelfel et al. 2010, 2014; Sevilgen et al. 2014). The production data were obtained from experiments with benthic chambers (ex and in situ), using samples from water depths of $\leq 5$ to $30 \mathrm{~m}$ (Woelfel et al. 2010, 2014), and oxygen microsensor measurements (ex and in situ) with samples at water depths of $\leq 5 \mathrm{~m}$ (Sevilgen et al. 2014).

Gross primary production rates (ex situ approach) ranged between 0.2 and $46 \mathrm{mmol} \mathrm{O} \mathrm{m}^{-2} \mathrm{~d}^{-1}$ at 18 sites in Kongsfjorden from $\leq 5 \mathrm{~m}$ to $30 \mathrm{~m}$ water depth (Woelfel et al. 2009). Three sites showed low but variable rates of net primary production (NPP) (in situ approach), ranging from -7.2 to $+14.4 \mathrm{mmol} \mathrm{O}_{2} \mathrm{~m}^{-2} \mathrm{~d}^{-1}$ (Woelfel et al. 2014). Based on these data, the numerical model of Walsby (1997) was applied to estimate seasonal and regional rates of near-shore NPP, using in situ photosynthesis-light curve parameters (derived during the same measuring campaign), total solar radiation, wind data and satellite-derived sea surface temperatures (SSTs). The highest daily NPP rates, calculated for the entire Arctic spring-summer season at depths $<15 \mathrm{~m}$, ranged from 15 to $18 \mathrm{mmol} \mathrm{O}_{2} \mathrm{~m}^{-2} \mathrm{~d}^{-1}$, slightly higher than but well in accordance with values determined from benthicchamber measurements. Primary production rates under stratified and fully mixed water-column conditions were also calculated by the model, which showed small differences $(<10 \%)$ between the two conditions (Woelfel et al. 2014).

Sevilgen et al. (2014) combined laboratory measurements of photosynthesis and respiration with in situ measurements of oxygen profiles and photon fluence rates, to derive daily oxygen budgets of 10.1-23.0 mmol $\mathrm{O}_{2} \mathrm{~m}^{-2} \mathrm{~d}^{-1}$ for one of the sites 
(Brandal) previously studied by Woelfel et al. (2010). While the latter authors based their calculations on fixed photon fluence rates that generally were higher than those measured under in situ light conditions, Sevilgen et al. (2014) integrated in situ photon fluence rates for their calculations. The two approaches resulted in only slightly different production rates, and confirmed the range of values derived from the benthic chambers.

The results of these studies highlight one of the most common problems in studying MPB primary production, namely the high degree of spatial and temporal heterogeneity (Glud et al. 2009; Sevilgen et al. 2014). This is explained by the typical heterogeneous micro- and mesoscale distribution (patchiness) of MPB abundance and community composition on sediments, which can change dynamically over both short and long time periods; as well as by methodological constraints such as the application of technological approaches (e.g. microsensors, benthic chambers), which can provide low numbers of replicates. All MPB production estimates for Kongsfjorden are within the same range as the data for pelagic primary production (Table 8.1).

\subsection{Grazing}

Grazing pressure is difficult to assess, and represents an obstacle to the comparison of MPB primary production from different habitats, as well as extrapolations to secondary production. Both the organic matter that is produced by benthic diatoms and the organic matter that originates from the overlying water column are consumed by herbi- or omnivorous grazers, mainly zoobenthos. Dense populations of macrozoobenthic organisms have been described for Arctic waters (Glud et al. 2009), as well as for soft sediments from different depths in Kongsfjorden (e.g. Brandal station) (Laudien et al. 2007). A dense infauna population at the same site (Brandal station, $5 \mathrm{~m}$ ) and correspondingly high respiration rates were documented by Sevilgen et al. (2014), with subsurface respiration rates 6 times higher $\left(-31.8 \mathrm{mmol} \mathrm{O}_{2} \mathrm{~m}^{-2} \mathrm{~d}^{-1}\right)$ than rates within the euphotic zone $\left(-5.4 \mathrm{mmol} \mathrm{O}_{2} \mathrm{~m}^{-2}\right.$ $\left.\mathrm{d}^{-1}\right)$.

High infaunal abundances can be linked to increased organic matter input from phytoplankton blooms. Spring blooms in Kongsfjorden produce a large amount of bio-available organic matter, which, if not grazed in the water column, sinks to the sea floor where it either is used directly or buried (Hodal et al. 2012). As discussed by Sevilgen et al. (2014), this spring bloom production can support a high abundance of infauna, which in turn affects the sediment biogeochemistry and the biomass of MPB, and consequently also their production rates. Thus, in addition to bottom-up factors that control MPB primary production, locally top-down mechanisms may also play an important role. 


\subsection{Benthic Diatoms as an Important Food Source}

Although the role of MPB communities as a food source has not yet been determined in Kongsfjorden, benthic diatoms are vitally important for ecological functioning in many other marine shallow-water habitats, where they can directly sustain grazers, deposit-feeders and suspension-feeders (Cahoon 1999). The MPB communities in Kongsfjorden, as in other regions, likely constitute an important trophic link, directly and indirectly, between bacteria and organisms at higher trophic levels, from micro- to meio- and macrofauna. Furthermore, benthic diatoms produce extracellular polymeric substances (EPS), an important source of carbohydrates for bacteria and deposit-feeders (Goto et al. 2001). Analysis of the gut contents and scanning electron microscopy examination of the benthic hydroid Silicularia rosea from intertidal communities of Potter Cove (King George Island, Antarctica) indicated that benthic diatoms comprised more than $95 \%$ of the food source (Gili et al. 1996). The same was true for Antarctic sponges and ascidians (Klöser 1994). The gastropod Nacella concinna is abundant along the Antarctic Peninsula (Brêthes et al. 1994) and feeds on benthic microalgae (Zacher et al. 2007). Furthermore, the abundance of benthic diatoms was correlated with the soma and gonad mass of N. concinna (Brêthes et al. 1994), which emphasises the trophic link between benthic microalgae and this gastropod. In a stable-isotope analysis $\left({ }^{13} \mathrm{C}\right)$, Corbisier et al. (2004) demonstrated the existence of a tight coupling between Antarctic benthic diatoms and benthic grazers, deposit-feeders and nematodes. Surprisingly, benthic diatoms proved to be an important food element for krill in both summer and winter, particularly when phytoplankton biomass was low (Ligowski 2000). In the Arctic, a detailed study of carbon cycling in a fjord system showed that the primary production of pelagic and ice algae could not meet the carbon requirements of the benthos, and hence benthic diatoms supplied a substantial part of their carbon intake (Glud et al. 2000; Rysgaard et al. 2001).

\subsection{Modern Approaches to Study Polar Benthic Diatoms}

Modern molecular approaches provide important information on gene expression and regulation in relation to stress and adaptation. In addition, these data help to distinguish whether the host diatom cell itself or the associated bacteria contribute to the mechanisms of interest. Over the last decade, various modern molecular genomic, transcriptomic, proteomic and metabolomic tools have been successfully applied to polar microalgae (reviewed by Lyon and Mock 2014), contributing to a new fundamental understanding of adaptation and acclimation mechanisms. Metagenomics and metatranscriptomics provide molecular tools to evaluate the 
biodiversity and ecology of all algae present at the same time, directly from an environmental sample (Tyson et al. 2004). Metagenomics is, in principle, even capable of sequencing nearly complete microbial genomes. The impact of the different stressors on algae under natural conditions can be assessed based on such results combined with transcriptomes of algae cultured under controlled stress conditions. In parallel with new developments in sequencing technologies, bioinformatic tools to process the enormous amounts of data generated have also improved.

A (meta)transcriptomic approach was undertaken for the first time on Kongsfjorden benthic diatoms in connection with a recent research project (B. Becker, University of Cologne, Germany). Cultures of Surirella cf. minuta were exposed to constant light or darkness for 1 week, followed by mRNA isolation and sequencing (Holzinger et al. 2014). About $80 \%$ of the analysed sequences yielded significant BLAST-Hits (BLAST: Basic Local Alignment Search Tool; Fig. 8.8), and nearly half could be functionally annotated. The BLAST results allowed easy assignment of the sequences to Surirella cf. minuta from Kongsfjorden, as well as to two bacteria species present in the culture. The top-hit species distribution of the BLAST analysis indicated that $55 \%$ of the sequences were represented by other diatoms (Phaeodactylum tricornutum, Thalassiosira oceanica, Thalassiosira

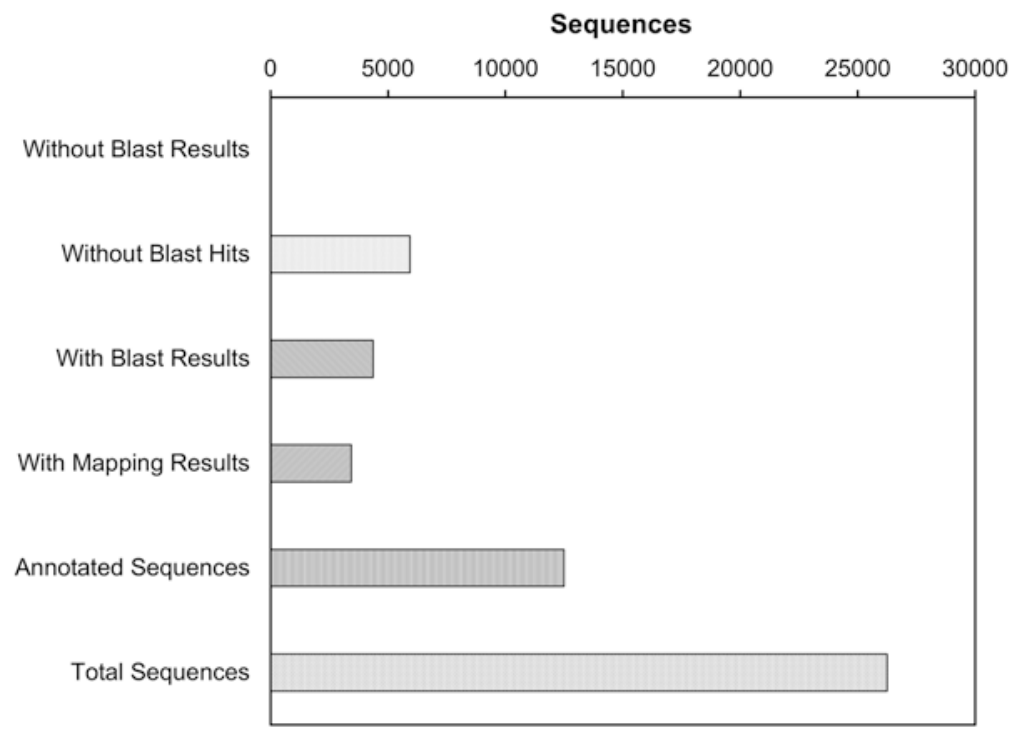

Fig. 8.8 Data distribution of the BLAST2GO (BLAST: Basic Local Alignment Search Tool) automatic annotation. About $23 \%$ of the Arctic benthic Surirella sequences yielded no BLAST hits. For $15 \%$ of the sequences, we retrieved similar proteins by BLAST, although the similarity was too low to map the sequences on KEGG pathways, and no Gene Ontology terms could be retrieved from the BLAST results. For roughly $50 \%$ of the sequences, the GO and/or KEGG mapping was specific enough that the putative function of the protein could be inferred, and the sequence was annotated. For $12 \%$ of the sequences, GO terms were retrieved, but the results were not specific enough to infer function 


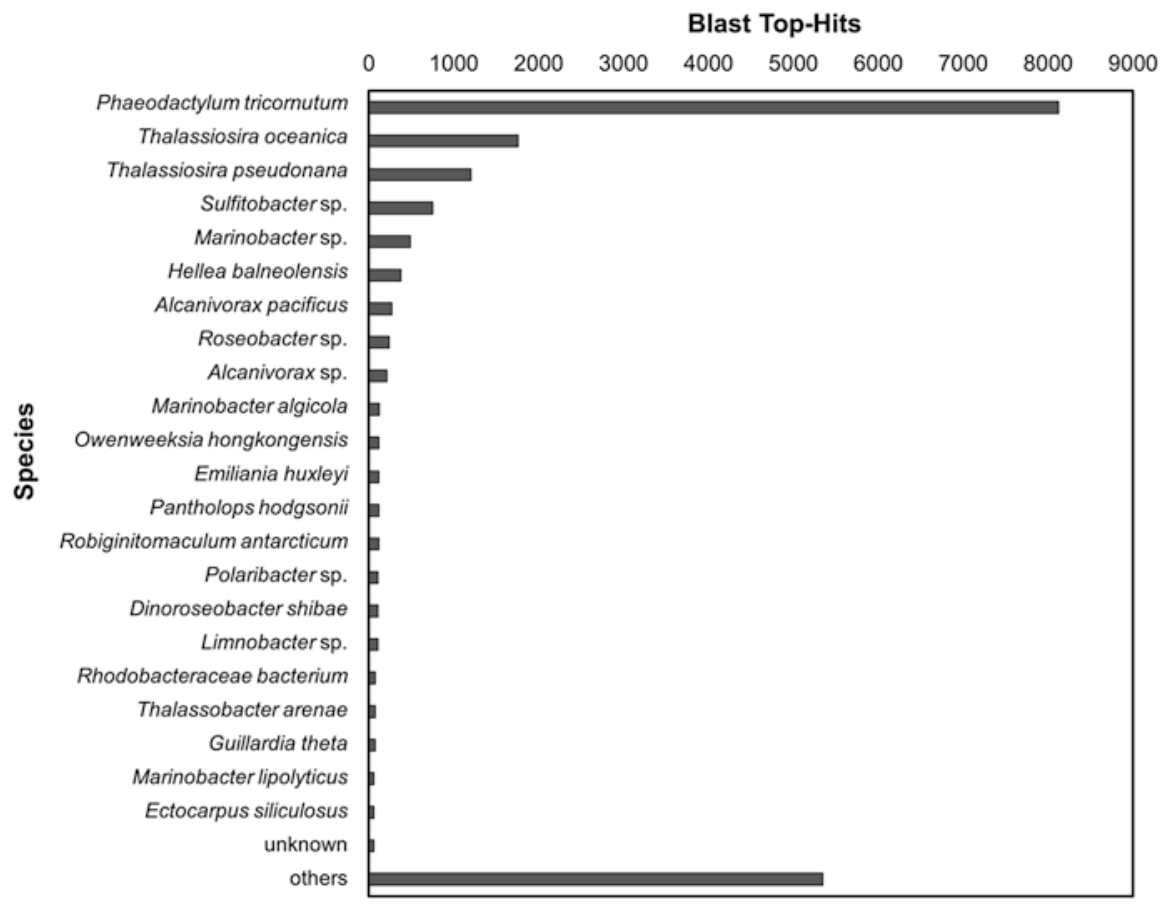

Fig. 8.9 Top-hit species distribution using about 26,000 contigs (a set of overlapping DNA segments that together represent a consensus region of DNA) with a length of at least 600 bases and the BLAST program as implemented in the BLAST2GO software (www.blast.ncbi.nlm.nih.gov/). BLAST (Basic Local Alignment Search Tool) is a bioinformatic tool for comparing primary biological sequence information, such as the nucleotides of DNA sequences, which can be used to help to identify members of gene families

pseundonana) (Fig. 8.9). Sequences related to Emiliania huxleyi, Ectocarpus siliculosus and Guillardia theta most likely also represent specific sequences from Surirella cf. minuta, since the genomes of diatoms are characterized by a complex combination of genes acquired from a variety of different source organisms (Armbrust 2009).

According to the BLAST analysis (Fig. 8.9), the two most frequent bacteria were a Marinobacter species ( $\gamma$-Proteobacteria) and a Sulfitobacter species $(\alpha$-Proteobacteria). Using known 16S rRNA sequences from both species, it was possible to find the corresponding rRNA sequences in the (meta)transcriptomic data. Blasting of the putative 16S rRNA sequences similar to Marinobacter 16S rRNA confirmed the presence of a Marinobacter species in the Surirella culture. However, the second bacterium proved to be an Algimonas species (an $\alpha$-proteobacterium related to Sulfitobacter). Algomonas has previously been isolated from a culture of Porphyra yezoenis (Fukui et al. 2013). It seems that both bacteria strongly interact with Surirella cf. minuta. 


\subsection{MPB Ecology in the Context of Global Warming and Outlook}

It has been estimated that the annual pelagic production of the Arctic Ocean has already increased by 5-6\% because of enhanced light availability (Arrigo et al. 2008). Based on field data from Kongsfjorden in combination with ecological modelling, Woelfel et al. (2014) concluded that rising temperatures in the Arctic will have only a marginally stimulating effect $(<3 \%)$ on MPB primary production.

Besides increasing light availability, the number of "newly" available shallowwater areas with different types of substrate is expected to expand. In recent decades, most of the fjordic tidal glaciers of Spitsbergen have been continuously regressing (e.g. Kongsbreen and Kongsvegen glaciers, inner Kongsfjorden; Lefauconnier et al. 1994; Kramer et al. 2013), thus providing new areas of seabed for settlement of benthic organisms (Włodarska-Kowalczuk et al. 1998). While bedrocks represent only $35 \%$ of the Arctic coastline, unlithified, ice-bonded sediments characterise $65 \%$ of the remaining coast (Lantuit et al. 2011). Ice-released sediments of the four Kongsfjorden glaciers will likely affect the fjord water regime (e.g. DOC load, turbidity). On the other hand, increasing meltwater runoff and precipitation may lead to a rise in the sea level, unless the isostatic rebound is higher (e.g. most of Svalbard). The effects of these changes (both individually and combined) on MPB ecology and primary production in the Arctic environment remain unstudied. Hence, more fieldwork, holistic/multi-factorial experiments and modelling approaches are needed to fill this gap in knowledge as well as to make realistic predictions for the future.

Higher temperatures generally stimulate metabolic activity, influencing both autotrophic and heterotrophic microbenthic organisms. In a subarctic spring community, the presence of benthic diatoms appeared to moderate the temperature response $\left(4{ }^{\circ} \mathrm{C}\right.$ elevation) of particularly heterotrophic but also autotrophic variables (Alsterberg et al. 2011). It was concluded that the photosynthetic activity of benthic diatoms could dampen the ecological consequences of global warming in shallow-water sediment systems, thus maintaining the system in a net-autotrophic state. Initial estimates have shown that a suggested increase of summer sea surface temperatures by $2{ }^{\circ} \mathrm{C}$, according to the IPCC scenario (A1B in 2007) and MacDonald (2010), would only marginally stimulate MPB NPP in Kongsfjorden (Woelfel et al. 2014). A sensitivity analysis of the model used clearly showed the crucial dependence of NPP on the $\mathrm{Q}_{10}$ values. Therefore, additional studies on $\mathrm{Q}_{10}$ values are needed for input into existing eco(physio)logical models, in order to improve their power. Interestingly, at least one study showed that increased $p \mathrm{CO}_{2}$ levels might have negative effects: the growth rate of the polar benthic diatom Navicula directa was reduced by $5 \%$ (Torstensson et al. 2012) when $p \mathrm{CO}_{2}$ rose from $380 \mathrm{ppm}$ to $960 \mathrm{ppm}$. In the same study, the combination of elevated temperature and increased $\mathrm{pCO}_{2}$ had no synergistic effects, but the growth rate at $4.5^{\circ} \mathrm{C}$ was $43 \%$ higher than at $0.5^{\circ} \mathrm{C}$.

In summary, stressors act synergistically, and although species-specific treatment responses of polar benthic diatoms are apparent, at the community level the effects on associated bacteria, grazers etc. could both reduce and enhance these effects. In 
the coming years, more long-term studies should be undertaken and permanent in situ observatories installed, which will aid our understanding of the annual performance and dynamics of MPB communities and their responses to changing environmental parameters in the course of global climate change. Deeper knowledge of the molecular mechanisms involved in bioenergetics, resource allocation, metabolic fluxes and community composition are expected to improve our ability to understand the influence of polar benthic diatoms on biogeochemical processes and the responses to global-change scenarios.

Acknowledgements Part of this study was performed at the Ny-Ålesund International Arctic Environmental Research and Monitoring Facility, under the agreement on scientific cooperation between the Alfred Wegener Institute and the University of Rostock. The authors thank the crew at the AWIPEV-base in Ny-Ålesund, the German dive team (P. Leopold, M. Schwanitz, I. Vieweg), and P. Kumm (workshop of the Institute of Chemistry, University of Rostock) for assistance in the field and technical equipment. Financing and logistical support of the research in Ny-Ålesund was kindly provided by the European Centre for Arctic Environmental Research (ARCFAC V; project no. 026129-02). Furthermore, we gratefully acknowledge financial support by the German Research Council in the framework of the Priority Programme 1158 (DFG, KA899/12-1/2/3, KA899/15-1/2/3).

\section{References}

Alsterberg C, Hulth S, Sundbäck K (2011) Response of a shallow-water sediment system to warming. Limnol Oceanogr 56:2147-2160

Armbrust EV (2009) The life of diatoms in the world's oceans. Nature 459:185-191

Armbrust EV, Berges J, Bowler C, Green BR, Martinez D, Putnam NH, Zhou S, Allen AE, Apt KE, Bechner M, Brzezinski M, Chaal BK, Chiovitti A, Davis AK, Demarest MS, Detter JD, Glavina T, Goodstein D, Hadi MZ, Hellsten U, Hildebrand M, Jenkins BD, Jurka J, Kapitonov VV, Kröger N, Lau WWY, Lane TW, Larimer FW, Lippmeier JC, Lucas S, Medina M, Montsant A, Obornik M, Parker MS, Palenik B, Pazour GJ, Richardson PM, Rynearson T, Saito M, Schwartz DC, Thamatrakoln K, Valentin K, Vardi A, Wilkerson FP, Rokhsar DS (2004) The genome of the diatom Thalassiosira pseudonana: ecology, evolution, and metabolism. Science 306:79-86

Arrigo KR, van Dijken G (2011) Secular trends in Arctic Ocean net primary production. J Geophys Res 116:C09011. https://doi.org/10.1029/2011JC007151

Arrigo KR, van Dijken G, Pabi S (2008) Impact of a shrinking Arctic ice cover on marine primary production. Geophys Res Lett 35:L19603. https://doi.org/10.1029/2008GL035028

Attard KM, Glud RN, McGinnis DF, Rysgaard S (2014) Seasonal rates of benthic primary production in a Greenland fjord measured by aquatic eddy correlation. Limnol Oceanogr 59:1555-1569

Beattie A, Hirst EL, Percival E (1961) Studies on the metabolism of the Chrysophyceae. Comparative structural investigations on leucosin (chrysolaminarin) separated from diatoms and laminarin from the brown algae. Biochem J 79:531-537

Bischof K, Hanelt D, Tüg H, Karsten U, Brouwer PEM, Wiencke C (1998) Acclimation of brown algal photosynthesis to ultraviolet radiation in Arctic coastal waters (Spitsbergen, Norway). Polar Biol 20:388-395

Bischof K, Hanelt D, Aguilera J, Karsten U, Vögele B, Sawall T, Wiencke C (2002) Seasonal variation in ecophysiological patterns in macroalgae from an Arctic fjord. I. Sensitivity of photosynthesis to ultraviolet radiation. Mar Biol 140:1097-1106 
Bischof K, Convey P, Duarte P, Gattuso J-P, Granberg M, Hop H, Hoppe C, Jiménez C, Lisitsyn L, Martinez B, Roleda MY, Thor P, Wiktor JM, Gabrielsen GW (this volume-c) Chapter 14: Kongsfjorden as harbinger of the future Arctic: knowns, unknowns and research priorities. In: Hop H, Wiencke C (eds) The ecosystem of Kongsfjorden, Svalbard, Advances in polar ecology 2. Springer, Cham

Brêthes J-C, Ferreyra G, de la Vega S (1994) Distribution, growth and reproduction of the limpet Nacella (Patinigera) concinna (Strebel 1908) in relation to potential food availability, in Esperanza Bay (Antarctic Peninsula). Polar Biol 14:161-170

Bunt JS, Lee CC (1972) Data on the composition and dark survival of four sea-ice microalgae. Limnol Oceanogr 17:458-461

Cahoon LB (1999) The role of benthic microalgae in neritic ecosystems. Oceanogr Mar Biol Annu Rev 37:47-86

Chapman ARO, Lindley JE (1980) Seasonal growth of Laminaria longicruris in the High Arctic in relation to irradiance and dissolved nutrient concentration. Mar Biol 57:1-5

Christie WW (1996) Separation of phospholipid classes by high-performance liquid chromatography. In: Christie WW (ed) Advances in lipid methodology, vol 3. The Oily Press, Dundee

Corbisier TN, Monica AV, Rodrigo P, Skowronski SP, Tania A, Brito S (2004) Trophic relationships in the nearshore zone of Martel Inlet (King George Island, Antarctica): ${ }^{13} \mathrm{C}$ stable-isotope analysis. Polar Biol 27:75-82

Cottier FR, Nilsen F, Inall ME, Gerland S, Tverberg V, Svendsen H (2007) Wintertime warming of an Arctic shelf in response to large-scale atmospheric circulation. Geophys Res Lett 34:L10607. https://doi.org/10.1029/2007GL029948

Darley WM (1977) Biochemical compostion. In: Werner D (ed) The biology of diatoms. University of California Press, Berkeley, pp 198-233

De Brouwer JFC, Wolfstein K, Ruddy GK, Jones TER, Stal LJ (2005) Biogenic stabilization of intertidal sediments: the importance of extracellular polymeric substances produced by benthic diatoms. Microb Ecol 49:501-512

Du GY, Oak JH, Li H, Chung IK (2010) Effect of light and sediment grain size on the vertical migration of benthic diatoms. Algae 25:133-140

Dunstan GA, Volkman JK, Barrett SM, Leroi JM, Jeffrey SW (1993) Essential polyunsaturated fatty acids from 14 species of diatom (Bacillariophyceae). Phytochemistry 35:155-161

Dunton KH (1990) Growth and production in Laminaria solidungula: relation to continuous underwater light levels in the Alaskan high Arctic. Mar Biol 106:297-304

Eilertsen HC, Taasen JP, Weslawski JM (1989) Phytoplankton studies in the fjords of West Spitsbergen: physical environment and production in spring and summer. J Plankton Res 11:1245-1260

Fredriksen S, Karsten U, Bartsch I, Woelfel J, Koblowsky M, Schumann R, Røang Moy S, Steneck B, Wiktor JM, Hop H, Wiencke C (this volume-c) Chapter 9: Biodiversity of benthic macroand microalgae from Svalbard with special focus on Kongsfjorden. In: Hop H, Wiencke C (eds) The ecosystem of Kongsfjorden, Svalbard, Advances in polar ecology 2. Springer, Cham

Fryxell GA (1989) Marine phytoplankton at the Weddell Sea ice edge: seasonal changes at the specific level. Polar Biol 10:1-18

Fukui Y, Kobayashi M, Saito H, Oikawa H, Yano Y, Satomi M (2013) Algimonas ampicilliniresistens sp. nov., isolated from the red alga Porphyra yezoensis, and emended description of the genus Algimonas. Int J Syst Evol Microbiol 63:4407-4412

Gattuso J-P, Gentili B, Duarte CM, Kleypas JA, Middelburg JJ, Antoinne D (2006) Light availability in the coastal ocean: impact on the distribution of benthic photosynthetic organisms and their contribution to primary production. Biogeosciences 3:489-513

Gili JM, Alva V, Pages F, Klöser H, Arntz WE (1996) Benthic diatoms as the major food source in the sub-Antarctic marine hydroid Silicularia rosea. Polar Biol 16:507-512

Glud RN, Risgaard-Petersen N, Thamdrup B, Fossing H, Rysgaard S (2000) Benthic carbon mineralization in a high-arctic sound. Mar Ecol Prog Ser 206:59-71 
Glud RN, Kühl M, Wenzhöfer F, Rysgaard S (2002) Benthic diatoms of a high Arctic fjord (Young Sound, NE Greenland): importance for ecosystem primary production. Mar Ecol Prog Ser 238:15-29

Glud RN, Woelfel J, Karsten U, Kühl M, Rysgaard S (2009) Benthic microalgal production in the Arctic: applied methods and status of the current database. Bot Mar 52:559-571

Goto N, Mitamura O, Terai H (2001) Biodegradation of photosynthetically produced extracellular organic carbon from intertidal benthic algae. J Exp Mar Biol Ecol 257:73-86

Graeve M, Janssen D (2009) Improved separation and quantification of neutral and polar lipid classes by HPLC-ELSD using a monolithic silica phase: application to exceptional marine lipids. J Chromatogr B 877:1815-1819

Gutt J (2001) On the direct impact of ice on marine benthic communities, a review. Polar Biol 24:553-564

Hanelt D, Tüg H, Bischof K, Gross C, Lippert H, Sawall T, Wiencke C (2001) Light regime in an Arctic fjord: a study related to Stratospheric Ozone depletion as a basis for determination of UV effects on algal growth. Mar Biol 138:649-658

Hegseth EN, Tverberg V (2013) Effect of Atlantic water inflow on timing of the phytoplankton spring bloom in a high Arctic fjord (Kongsfjorden, Svalbard). J Mar Syst 113-114:94-105

Hellebust JA, Lewin J (1977) Heterotrophic nutrition. In: Werner D (ed) The biology of diatoms. University of California Press, Berkeley, pp 169-197

Hodal H, Falk-Petersen S, Hop H, Kristiansen S, Reigstad M (2012) Spring bloom dynamics in Kongsfjorden, Svalbard: nutrients, phytoplankton, protozoans and primary production. Polar Biol 35:191-203

Holzinger A, Kaplan F, Blaas K, Zechmann B, Komsic-Buchmann K, Becker B (2014) Transcriptomics of desiccation tolerance in the streptophyte green alga Klebsormidium reveal a land plant-like defense reaction. PLoS One 9(10):e110630

Hop H, Pearson T, Hegseth EN, Kovacs KM, Wiencke C, Kwasniewski S, Eiane K, Mehlum F, Gulliksen B, Wlodarska-Kowalzuk M, Lydersen C, Weslawski JM, Cochrane S, Gabrielsen GW, Leakey RJG, Lønne OJ, Zajaczkowski M, Falk-Petersen S, Kendall M, Wängberg S-Å, Bischof K, Voronkov AY, Kovaltchouk NA, Wiktor J, Poltermann M, di Prisco G, Papucci C, Gerland S (2002) The marine ecosystem of Kongsfjorden, Svalbard. Polar Res 21:167-208

Hsiao SIC (1988) Spatial and seasonal variations in primary production of sea ice microalgae and phytoplankton in Frobisher Bay, Arctic Canada. Mar Ecol Prog Ser 44:275-285

IPCC AR4 WG1 (2007) In: Solomon S, Qin D, Manning M, Chen Z, Marquis M, Averyt KB, Tignor M, Miller HL (eds) Climate change 2007: the physical science basis, contribution of Working Group I to the Fourth Assessment Report of the Intergovernmental Panel on Climate Change, Cambridge University Press

Jakobsson MR, Macnab R, Mayer L, Andersson R, Edwards M, Hatzky J, Schenke HW, Johnson P (2008) An improved bathymetric portrayal of the Arctic Ocean: implications for ocean modeling and geological, geophysical and oceanographic analysis. Geophys Res Let 35:L07602. https://doi.org/10.1029/2008/2008g1033520

Jerlov NG (1976) Marine optics. Elsevier, Amsterdam

Karsten U, Schumann R, Rothe S, Jung I, Medlin L (2006) Temperature and light requirements for growth of two diatom species (Bacillariophyceae) isolated from an Arctic macroalga. Polar Biol 29:476-486

Karsten U, Schlie C, Woelfel J, Becker B (2012) Benthic diatoms in Arctic seas - ecological functions and adaptations. Polarforschung 81:77-84

Kattner G, Fricke HSG (1986) Simple gas-liquid chromatographic method for the simultaneous determination of fatty acids and alcohols in wax esters of marine organisms. J Chromatogr 361:263-268

Klöser H (1994) Microphytobenthos as a food for filter feeding animals in Maxwell Bay. SCAR 6th Biology Symposium: Antarctic communities: species, structure and survival. Abstracts. SCAR, Venice, Italy, p 153 
Kramer F, Obleitner F, Krismer T, Kohler J, Greuell W (2013) A decade of energy and mass balance investigations on the glacier Kongsvegen, Svalbard. J Geophys Res Atmos 118:3986-4000

Kühl M, Glud RN, Borum R, Roberts R, Rysgaard S (2001) Photosynthetic performance of surface-associated algae below sea ice as measured with a pulse-amplitude-modulated (PAM) fluorometer and $\mathrm{O}_{2}$ microsensors. Mar Ecol Prog Ser 223:1-14

Kwasniewski S, Głuchowska M, Walkusz W, Karnovsky NJ, Jakubas D, Wojczulanis-Jakubas K, Harding AMA, Goszczko I, Cisek M, Beszczyńska-Möller A, Walczowski W, Weslawski JM, Stempniewicz W (2012) Inter-annual changes in zooplankton on the West Spitsbergen Shelf in relation to hydrography, and their consequences for the diet of planktivorous seabirds. ICES J Mar Sci 69:890-901

Lamb MA, Lowe RL (1987) Effects of current velocity on the physical structuring of diatom (Bacillariophyceae) communities. Ohio J Sci 87:72-78

Lantuit H, Overduin PP, Couture N, Wetterich S, Aré F, Atkinson D, Brown J, Cherkashov G, Drozdov D, Forbes DL, Graves-Gaylord A, Grigoriev M, Hubberten HW, Jordan J, Jorgenson T, Ødegård RS, Ogorodov S, Pollard W, Rachold V, Sedenko S, Solomon S, Steenhuisen F, Streletskaya I, Vasiliev A (2011) The Arctic coastal dynamics database: a new classification scheme and statistics on Arctic permafrost coastlines. Estuar Coast 35:383-400

Laudien J, Herrmann M, Arntz W (2007) Soft bottom species richness and diversity as a function of depth and iceberg scour in Arctic glacial Kongsfjorden (Svalbard). Polar Biol 30:1035-1046

Laxon SW, Giles KA, Ridout AL, Wingham DJ, Willatt R, Cullen R, Kwok R, Schweiger A, Zhang JL, Haas C, Hendricks S, Krishfield R, Kurtz N, Farrell S, Davidson M (2013) CryoSat-2 estimates of Arctic sea ice thickness and volume. Geophys Res Lett 40:732-737

Lefauconnier B, Hagen JO, Rudant JP (1994) Flow speed and calving rate of Kongsbreen glacier, Svalbard, using SPOT images. Polar Res 13:59-65

Ligowski R (2000) Benthic feeding by krill, Euphausia superba Dana, in coastal waters off West Antarctica and in Admiralty Bay, South Shetland Islands. Polar Biol 23:619-625

Longhi ML, Schloss IR, Wiencke C (2003) Effect of irradiance and temperature on photosynthesis and growth of two Antarctic benthic diatoms, Gyrosigma subsalinum and Odontella litigiosa. Bot Mar 46:276-284

Longphuirt SN, Leynaert A, Guarini JM, Chauvaud L, Claquin P, Herlory O, Amice E, Huonnic P, Ragueneau O (2006) Discovery of microphytobenthos migration in the subtidal zone. Mar Ecol Prog Ser 328:143-154

Lyon BR, Mock T (2014) Polar microalgae: new approaches towards understanding adaptations to an extreme and changing environment. Biology 3:56-80

MacDonald GM (2010) Global warming and the Arctic: a new world beyond the reach of the Grinnellian niche? J Exp Biol 213:855-861

McGee D, Laws RA, Cahoon LB (2008) Live benthic diatoms from the upper continental slope: extending the limits of marine primary production. Mar Ecol Prog Ser 356:103-112

McMinn A, Martin A (2013) Dark survival in a warming world. Proc R Soc B 280(1755):20122909

McQuoid MR, Hobson LA (1996) Diatom resting stages. J Phycol 32:889-902

Menard H, Smith SM (1966) Hypsometry of ocean basin provinces. J Geophys Res 71:4305-4325

Nordbäck J, Lundberg E, Christie WW (1998) Separation of lipid classes from marine particulate material by HPLC on a polyvinyl alcohol-bonded stationary phase using dual-channel evaporative light-scattering detection. Mar Chem 60:165-175

Overland JE, Wang M, Walsh JE, Stroeve JC (2014) Future Arctic climate changes: adaptation and mitigation time scales. Earths Future 2:68-74

Palmisano AC, Sullivan CW (1982) Physiology of sea ice diatoms. I. Response of three polar diatoms to a simulated summer-winter transition. J Phycol 18:489-498

Palmisano AC, Sullivan CW (1983) Physiology of sea ice diatoms. II. Dark survival of three polar diatoms. Can J Microbiol 29:157-160

Palmisano AC, Sullivan CW (1985) Growth, metabolism, and dark survival in sea ice microalgae. In: Horner RA (ed) Sea Ice Biota. CRC Press, Boca Raton, pp 131-146 
Palmisano AC, Soohoo JB, White DC, Smith GA, Stanton GA, Burckle GR (1985) Shade adapted benthic diatoms beneath Antarctic sea ice. J Phycol 21:664-667

Pavlov A, Leu E, Hanelt D, Bartsch I, Karsten U, Hudson SR, Gallet J-C, Cottier F, Cohen JH, Berge J, Johnsen G, Maturilli M, Kowalczuk P, Sagan S, Meler J, Granskog MA (this volume-d) Chapter 5: Underwater light regime in Kongsfjorden and its ecological implications. In: Hop H, Wiencke C (eds) The ecosystem of Kongsfjorden, Svalbard, Advances in polar ecology 2. Springer, Cham

Pavlova O, Gerland S, Hop H (this volume-d) Chapter 4: Changes in sea-ice extent and thickness in Kongsfjorden, Svalbard (2003-2016). In: Hop H, Wiencke C (eds) The ecosystem of Kongsfjorden, Svalbard, Advances in polar ecology 2. Springer, Cham

Peters E, Thomas DN (1996) Prolonged darkness and diatom mortality I: marine antarctic species. J Exp Mar Biol Ecol 207:25-41

Petrowski S, Molis M, Schachtl K, Buschbaum C (2016) Do bioturbation and consumption affect coastal Arctic marine soft-bottom communities? Polar Biol 39:2141-2153

Piepenburg D, Blackburn TH, von Dorrien CF, Gutt J, Hall POJ, Hulth S, Kendall MA, Opalinski KW, Rachor E, Schmid MK (1995) Partitioning of benthic community respiration in the Arctic (northwestern Barents Sea). Mar Ecol Prog Ser 118:199-213

Polyakov IV, Beszczynska A, Carmack EC, Dmitrenko IA, Fahrbach E, Frolov IE, Gerdes R, Hansen E, Holfort J, Ivanov VV, Johnson MA, Karcher M, Kauker F, Morison J, Orvik KA, Schauer U, Simmons HL, Skagseth $\varnothing$, Sokolov VT, Steele M, Timokhov LA, Walsh D, Walsh JE (2005) One more step toward a warmer Arctic. Geophys Res Lett 32:L17605

Risgaard-Petersen N, Rysgaard S, Nielsen LP, Revsbech NP (1994) Diurnal variation of dentrification and nitrification in sediments colonized by benthic microphytes. Limnol Oceanogr 39:573-579

Rysgaard S, Thamdrup B, Risgaard-Petersen N, Fossing H, Berg P, Bondo PB, Dalsgaard T (1998) Seasonal carbon and nutrient mineralisation in a high-Arctic coastal marine sediment, Young Sound, NE Greenland. Mar Ecol Prog Ser 175:261-276

Rysgaard S, Nielsen TG, Hansen BW (1999) Seasonal variation in nutrients, pelagic primary production and grazing in a high-Arctic coastal marine ecosystem, Young Sound, NE Greenland. Mar Ecol Prog Ser 179:13-25

Rysgaard S, Kühl M, Glud RN, Würgler Hansen J (2001) Biomass, production and horizontal patchiness of sea ice algae in a high-Arctic fjord (Young Sound, NE Greenland). Mar Ecol Prog Ser 223:15-26

Salleh S, McMinn A (2011) Photosynthetic response and recovery of Antarctic marine benthic microalgae exposed to elevated irradiances and temperatures. Polar Biol 34:855-869

Schaub I, Wagner H, Graeve M, Karsten U (2017) Effects of prolonged darkness and temperature on the lipid metabolism in the benthic diatom Navicula perminuta from the Arctic Adventfjorden, Svalbard. Polar Biol 40:1425-1439

Schlie C, Karsten U (2017) Microphytobenthic diatoms isolated from the Arctic Adventfjorden (Svalbard) - growth as function of temperature. Polar Biol 40:1043-1051

Schlie C, Woelfel J, Rüdiger F, Schumann R, Karsten U (2011) Ecophysiological performance of benthic diatoms from arctic waters. In: Seckbach J, Kociolek P (eds) The diatom world. Cellular origin, life in extreme habitats and astrobiology, vol 19. Springer, Berlin, pp 425-436

Sejr MK, Jensen KT, Rysgaard S (2000) Macrozoobenthic structure in a high-Arctic east Greenland fjord. Polar Biol 23:792-801

Serreze MC, Francis JA (2006) The Arctic on the fast track of change. Weather 61:65-69

Serreze MC, Holland MM, Stroeve J (2007) Perspectives on the Arctic's shrinking sea-ice cover. Science 315:1533-1536

Sevilgen DS, de Beer D, Al-Handal AY, Brey T, Polerecky L (2014) Oxygen budgets in subtidal arctic (Kongsfjorden, Svalbard) and temperate (Helgoland, North Sea) microphytobenthic communities. Mar Ecol Prog Ser 504:27-42

Shimizu K, Del Amo Y, Brzezinski MA, Stucky GD, Morseemail DE (2001) A novel fluorescent silica tracer for biological silicification studies. Chem Biol 8:1051-1060 
Smith AE, Morris I (1980) Synthesis of lipid during photosynthesis by phytoplankton of the southern ocean. Science 207:197-199

Stachura-Suchoples K, Enke N, Schlie C, Schaub I, Karsten U, Jahn R (2016) Contribution towards a molecular taxonomic reference library of Arctic benthic marine diatoms from Kongsfjorden. Polar Biol 39:1933-1956

Sukenik A, Wahnon R (1991) Biochemical quality of marine unicellular algae with special emphasis on lipid-composition. I. Isochrysis galbana. Aquaculture 97:61-72

Svendsen H, Beszczynska-Møller A, Hagen JO, Lefauconnier B, Tverberg V, Gerland S, Ørbæk JB, Bischof K, Papucci C, Zajaczkowski M, Azzolini R, Bruland O, Wiencke C, Winther J-G, Dallmann W (2002) The physical environment of Kongsfjorden - Krossfjorden, an Arctic fjord system in Svalbard. Polar Res 21:133-166

Thomas DN, Fogg GE, Convey P, Fritsen CH, Gili JM, Gradinger R, Laybourn-Parry J, Reid K, Walton DWH (2008) The biology of polar regions. Oxford, Oxford University Press, $394 \mathrm{p}$

Torstensson A, Chierici M, Wulff A (2012) The influence of increased temperature and carbon dioxide levels on the benthic/sea ice diatom Navicula directa. Polar Biol 35:205-214

Tyson GW, Chapman J, Hugenholtz P, Allen EE, Ram RJ, Richardson PM, Solovyev VV, Rubin EM, Rokhsar DS, Banfield JF (2004) Community structure and metabolism through reconstruction of microbial genomes from the environment. Nature 428(6978):37-43

Veldhuis MJW, Cucci TL, Sieracki ME (1997) Cellular DNA content of marine phytoplankton using two new fluorochromes: taxonomic and ecological implications. J Phycol 33:527-541

Wagner H, Liu Z, Langner U, Stehfest K, Wilhelm C (2010) The use of FTIR spectroscopy to assess quantitative changes in the biochemical composition of microalgae. J Biophotonics 3:557-566

Wagner H, Jungandreas A, Fanesi A, Wilhelm C (2014) Surveillance of C-allocation in microalgal cells. Meta 4:453-464

Walsby AE (1997) Numerical integration of phytoplankton photosynthesis through time and depth in a water column. New Phytol 136:189-209

Wiencke C (ed) (2004) The coastal ecosystem of Kongsfjorden, Svalbard. Synopsis of biological research performed at the Koldewey Station in the years 1991-2003. Ber Polarforsch Meeresforsch 492:1-244

Wiencke C, tom Dieck I (1990) Temperature requirements for growth and survival of macroalgae from Antarctica and southern Chile. Mar Ecol Prog Ser 59:157-170

Włodarska-Kowalczuk M, Węslawski JM, Kotwicki L (1998) Spitsbergen glacial bays macrobenthos - a comparative study. Polar Biol 20:66-73

Woelfel J, Schumann R, Leopold P, Wiencke C, Karsten U (2009) Microphytobenthic biomass along gradients of physical conditions in Arctic Kongsfjorden, Svalbard. Bot Mar 52:573-583

Woelfel J, Schumann R, Peine F, Flohr A, Flohr A, Kruss A, Tegowski J, Blondel P, Wiencke C, Karsten U (2010) Microphytobenthos of Arctic Kongsfjorden (Svalbard, Norway): biomass and potential primary production along the shore line. Polar Biol 33:1239-1253

Woelfel J, Eggert A, Karsten U (2014) Marginal impacts of rising temperature on Arctic benthic microalgae production based on in situ measurements and modelled estimates. Mar Ecol Prog Ser 501:25-40

Wulff A, Roleda MY, Zacher K, Wiencke C (2008) Exposure to sudden light burst after prolonged darkness - a case study on benthic diatoms in Antarctica. Diat Res 23:519-532

Wulff A, Iken K, Quartino ML, Al-Handal A, Wiencke C, Clayton MN (2009) Biodiversity, biogeography and zonation of benthic micro- and macroalgae in the Arctic and Antarctic. Bot Mar 52:491-507

Zacher K, Hanelt D, Wiencke C, Wulff A (2007) Grazing and UV radiation effects on an Antarctic intertidal microalgal assemblage - a long-term field study. Polar Biol 30:1203-1212

Zhang Q, Gradinger R, Spindler M (1998) Dark survival of marine microalgae in the high Arctic (Greenland Sea). Polarforschung 65:111-116

Zhang JL, Lindsay R, Schweiger A, Rigor I (2012) Recent changes in the dynamic properties of declining Arctic sea ice: a model study. Geophys Res Lett 39. https://doi.org/10.1029/201 2GL053545 